\title{
POSTPRINT \\ Phonological constraints on English word formation
}

\author{
RENATE RAFFELSIEFEN
}

\section{INTRODUCTION}

In English, vowel-initial suffixation differs from consonant-initial suffixation in that it exhibits phonological effects. These include both phonologically conditioned gaps and systematic variations of the phonological structure of stem or suffix (i.e. allomorphy). Arguably both types of effects are closely related in that they allow satisfaction of phonological constraints in morphological output forms. Reference to the output rather than the input of affixation is necessary because the relevant constraints would be violated only as a result of combining the specific phonological forms of stems and affixes. I will argue that reference to output forms alone is sufficient for a description of English morphophonology if a) output forms are represented phonemically rather than phonetically and b) there are constraints which require certain features of derived words to be identical to the corresponding features in their base (cf. Benua 1995; Burzio 1994; McCarthy and Prince 1995; Raffelsiefen 1992, 1996).

While no two vowel-initial suffixes in English exhibit exactly the same phonological effects we find that all such effects can be described in terms of a few independently motivated constraints. The differences between suffixes result from different constraint rankings. The acquisition of English morphophonology can thus be described as the association of a specific constraint ranking with each suffix.

The fact that consonant-initial suffixes exhibit no phonological effects correlates with the observation that they are not integrated into the pword (i.e. phonological word) of the stem where the pword is defined as the domain for syllabification. For English, it holds then that suffixes exhibit phonological effects only when they are integrated into the pword of the stem. The observation that the pword constitutes the domain for phonological constraints in word formation does not hold crosslinguistically but rather must be considered a language-specific property of English.

In contrast to most generative work on English morphology the description presented here is limited to native word-formation because native formations obey a range of restrictions which loan words do not. This does not imply that English speakers lack intuitions regarding the relatedness between loan words. However, there is evidence that such intuitions are best described within a model of analysis for which the constraints differ from those on the synthesis of new words.

The paper is structured as follows. In section 2 I motivate the limitation of the data to native word formation. Evidence for a fundamental distinction between vowel-initial and consonant-initial suffixation in English is presented in section 3 . Section 4 contains a discussion of various phonological effects in English suffixation and their analysis in terms of ranked constraints. Data which may appear to contradictthe claim that consonant-initial suffixes show no phonological effects are examined in section 5. The prosodic structure of English suffixed words is described 
in section 6. In section $7 \mathrm{I}$ discuss the issue of abstractness arguing that only the phonemic level is relevant for the description of phonological effects in word formation. The analysis presented here is contrasted with previous work in section 8 . In section 9 I present some evidence for my claim that morphological analysis is subject to specific phonological restrictions which differ from the conditions on synthesis (i.e. native word formation). In section $10 \mathrm{I}$ discuss the issue of input versus output constraints in morphology and summarize the main conclusions of this paper.

\section{SELECTION OF THE DATA}

The description of English word formation presented below is based on native suffixation and native speaker intuitions regarding the acceptability of nonce formations. Loanwords are generally omitted from consideration which is not to deny that they can be analysed and related to other words by hearers. The omission of loanwords is motivated by the observation that the conditions for the analysis of given words differ from the conditions for the synthesis of new words (cf. section 9). When considering native coinages one should keep in mind that the phonological conditions under which a word was formed may have been obscured by subsequent historical sound changes. Consider the plural forms in (1a), which were derived in English but have subsequently been affected by historical changes like umlaut, front vowel derounding, fricative devoicing, schwa loss, etc.
(1)a. mouse $]_{S G}-$ mice $]_{P L}$
man $\left.]_{S G}-\operatorname{men}\right]_{P L}$
thief] $]_{S G}$ - thieves $]_{P L}$
b. spouse $_{\mathrm{SG}}{ }^{*}{ }^{*}$ spice $]_{\mathrm{PL}}$
plan $]_{S G}-{ }^{*}$ plen $]_{\mathrm{PL}}$
chief] $]_{S G}-{ }^{*}$ chieves $]_{P L}$
hou[s]e $]_{S G}-$ hou[z]es $]_{P L}$
$\left.\mathrm{ca}[\mathrm{s}] \mathrm{e}]_{\mathrm{SG}}-\mathrm{ca}[\mathrm{z}] \mathrm{es}\right]_{\mathrm{PL}}$

While the historical stability of the plural-singular relations in (1a) shows that they are consistently recognized by English learners the nonce plural formations in (1b) show that analogous coinages are unacceptable. This sort of observation motivates a separate description of the conditions for morphological analysis (i.e. recognition of relatedness between given words) and morphological synthesis (i.e. the formation of new words). Evidence that the recognition of relatedness between the words in (1a) is subject to independent phonological constraints is presented in section 9 .

Strong support for the claim that the conditions for morphological synthesis and analysis should be described separately comes from words which have undergone historical reanalysis. Consider the noun forgiveness, which seems to contradict the claim that the suffix -ness attaches only to adjectives. Significantly, forgiveness was originally derived from the adjective forgiven and subsequently underwent degemination and schwa deletion (i.e. forgivenness $>$ forgiveness). Due to these phono- 
logical changes learners began to relate the noun to the verb forgive as is manifested by its current deverbal interpretation (i.e. 'the act of forgiving') as opposed to its original deadjectival interpretation (i.e. 'the condition of being forgiven'). However, while forgiveness is analysable as a deverbal noun, there is no evidence that it could be coined as such. In fact, no -ness suffixation based on verbs is attested and nonce nouns such as *forgetness, ${ }^{*}$ forbidness are clearly unacceptable. This example shows that words which have undergone historical reanalysis may obscure the conditions for forming new words and should therefore be omitted from consideration.

Consider next the nouns burial and trial, which are often cited as counterexamples to the claim that the noun-forming suffix -al combines only with iambic verbs (cf. survíval, withdráwal, rehéarsal). Neither of these nouns was coined in English by suffixing - al to a verb: burial is a reanalysis of the Old English plural form byrgels (i.e. OE byrgels $>$ ME biriel $>$ NE burial) and trial is a reanalysed loan word (i.e. Norman French triel). Although there is evidence that English learners synchronically analyse these nouns as -al suffixation based on the verbs bury and try, respectively, trochaic or monosyllabic verbs have never served as a base for native $-a l$ suffixation. There is no reason to expect that the prosodic restriction on productive -al suffixation to iambic bases would block the adoption of loanwords ending in [əl] which happen to lack iambic cognates in English. The conditions for both the adoption and the analysis of loanwords differ from the conditions on native word formation and should therefore be described separately.

\section{VOWEL-INITIAL VERSUS CONSONANT-INITIAL SUFFIXES IN ENGLISH}

In descriptions of English morphophonology two types of affixes have been traditionally distinguished: those which 'fuse' phonologically with their stem versus those which are 'neutral' w.r.t. their stem (cf. Newman 1946). For the former type, illustrated in (2a), the stress 'shifts' in accordance with English stress patterns for nouns or adjectives (i.e. antepenultimate stress if the penultimate syllable is open, penultimate stress if that syllable is closed). 'Neutrality' is illustrated by the examples in (2b).

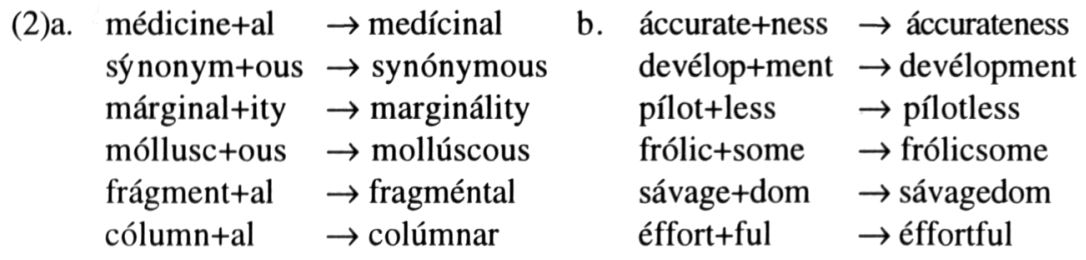

In generative descriptions the two types of affixes are generally distinguished in terms of boundaries or levels to ensure that stress rules apply after suffixation in (2a) but before suffixation in (2b) (cf. Chomsky and Halle 1968; Siegel 1974). On those approaches the morphophonological behavior of affixes depends on class member- 
ship, which is encoded by a diacritic feature. However, as noted by Booij (1985) that behavior appears to be partly determined by the affixal shape: consonant-initial suffixes are generally neutral, whereas most vowel-initial suffixes fuse with the stem. The distinct phonological effects of the suffixes in (2) could thus be described by assuming that the pword is the domain of the English stress rule and by stipulating that vowel-initial suffixes, but not consonant-initial suffixes, are integrated into the pword of their stem as shown in (3).
(3)a. (medícinal) $\omega$
(synónymous) $\omega$
(rurálity) $\omega$
(mollúscous) $\omega$
(fragméntal) $\omega$
(colúmnar) $\omega$
b. (áccurate) $\omega^{\text {ness }}$
(devélop) $\omega$ ment
(pílot) $\omega_{1 \text { less }}$
(frólic) $\omega^{\text {some }}$
(sávage) $)_{\text {dom }}$
(éffort) $\omega_{\text {ful }}$

Assuming that pwords constitute the domain for syllabification one should expect that stem-final consonants appear in onset position in vowel-initial suffixation ${ }^{2}$ and in coda position in consonant-initial suffixation. Consider the different realizations of the voiceless labial stops in the near-minimal pairs in (4a) in careful pronunciation. According to Kahn (1976), voiceless stops are aspirated in syllable-initial position (cf. [ $\left.\mathrm{p}^{\mathrm{h}}\right]$ lacenta, sur[ $\left.\left.\mathrm{p}^{\mathrm{h}}\right] l u s\right)^{3}$ but unreleased in syllable-final position (cf. $t i\left[\mathrm{p}^{\prime}\right]$, $\left.\operatorname{har}\left[\mathrm{p}^{\prime}\right]\right) .{ }^{4}$ If this generalization is correct the derived words in (4a) have the syllable structures in (4b): 5

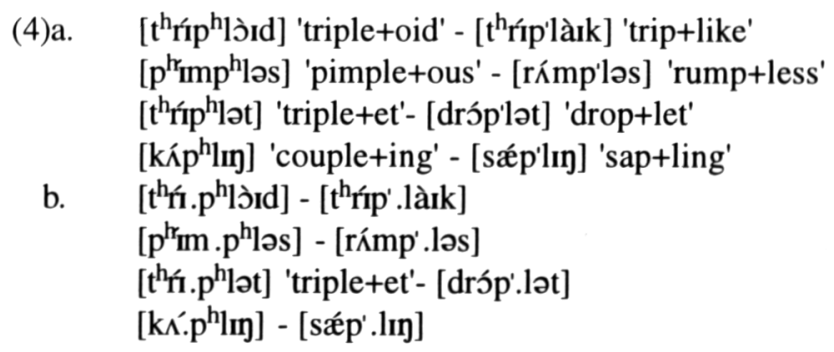

The structures in (4b) indicate that words with vowel-initial suffixes consistently obey the LOI (i.e. Law of Initials) whereas words with consonant-initial suffixes do not. ${ }^{6}$ The violations of the LOI result from the syllabification of stem-final consonants in coda position. They thereby indicate the pword structures in (5), which show integration of vowel-initial, but not consonant-initial, suffixes. ${ }^{7}$

$$
\begin{aligned}
& \text { (triploid) } \omega-(\text { trip })_{\omega} \text { like }^{8} \\
& \text { (pimplous) } \left.)^{-} \text {(rump) }\right)_{\omega} \text { less } \\
& \text { (triplet) })_{\omega}-(\text { drop })_{\omega} \text { let } \\
& \text { (coupling })_{\omega}-(\text { sap })_{\omega} \text { ling }
\end{aligned}
$$


The distinct prosodic structures in (5) are natural in that only the suffixes which inherently lack a syllable onset fuse into one pword with their stem. According to McCarthy and Prince (1993) this type of condition is characteristic of prosodic morphology, in that a phonological constraint, the requirement that syllables must have onsets, dominates morphological alignment constraints (cf. section 6).

The stress shift in the words which include vowel-initial suffixes in (2) is explained under the assumptions that such suffixes are integrated into the pword of the stem and that the pword is the domain for the English stress rule. Within constraint-based frameworks this phonological effect can be partially expressed by a constraint which requires the right edge of a maximally dactylic foot to align with the right edge of the pword (for discussion and alternative approaches cf. McCarthy and Prince 1993; Pater 1995).

(6) a. F

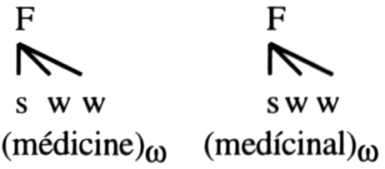

b. F

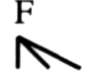

S W W

(áccurate) $\omega$

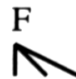

S W w

(áccurate) $\omega$ ness

Without stress shift the attachment of a stressless suffix like -al to words which end in two stressless syllables (e.g. médicine) would violate the constraint which restricts the size of wordfinal feet to dactyls. However, the examples in (7) show that this constraint is not obeyed in all words derived by vowel-initial suffixes:

$$
\begin{array}{lll}
\text { vínegar+ish } & \rightarrow & \text { vínegarish } \\
\text { áccurate+acy } & \rightarrow & \text { áccuracy } \\
\text { ínjure+able } & \rightarrow & \text { ínjurable }
\end{array}
$$

Not all, but only vowel-initial suffixes can induce stress shifts. The fact that the vowel-initial suffixes in (7) are consistently stress-neutral might indicate that some vowel-initial suffixes are not integrated into the pword of the stem. However, since all of these suffixes exhibit other phonological effects, their stress-neutrality is best described by ranking the constraint IDENT(S), which is stated in (8) (cf. Benua 1995; Burzio 1994; McCarthy and Prince 1995; Raffelsiefen 1992, 1996), higher than the phonological constraint which requires the right edge of the pword to align with maximally dactylic feet. ${ }^{9}$ Identity constraints refer to certain aspects of phonological structure since there are affixes which require the identity of some, but not all, features. 10

\section{IDENT(S)}

A stressed syllable in a derived word must correspond to a stressed syllable in the base.

Unlike stress, syllabification is not affected by identity constraints in English. There 
are accordingly no suffixes which idiosyncratically require speech sounds occurring in a specific syllable position in the base to occur in the same position in the derived word.11 Instead syllabification is determined entirely by its domain, the pword, and phonological constraints like the LOI. 12

It is the aim of this paper to show that English morphophonology is most adequately described in terms of an interaction between phonological constraints, whose domain is the pword, and identity constraints which refer to the relation between a derived word and its base. Both allomorphy and gaps in word formation reflect the avoidance of constraint violations which would arise as a result of attaching an affix to a stem. The phonological effects which occur in affixation are shown in figure (9):

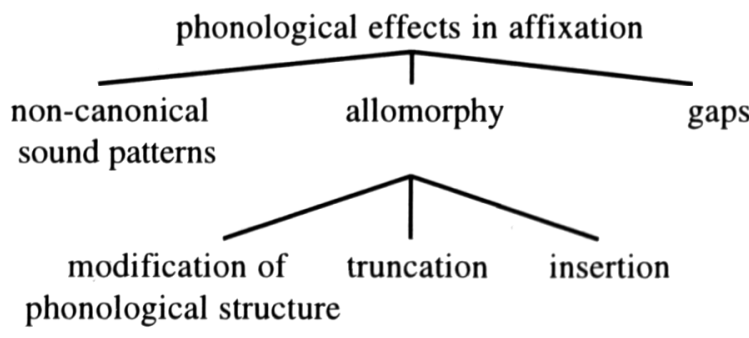

Non-canonical sound patterns refer to any segmental and suprasegmental sound structure within pwords which does not occur in underived words. Such patterns are subsumed under phonological effects in affixation because they result from the concatenation of the (unmodified) phonological structures of stems and affixes (cf. the stress patterns in (7)). The term 'allomorphy' and its hyponyms do not designate types of phonological changes but rather describe the relation between (the phonemic form of) affixed words and their base. Specifically, allomorphy indicates the low ranking of identity constraints w.r.t. phonological constraints. For example, the stress difference in the noun ràdicálity and its base rádical does not indicate that the stress has shifted in the noun (cf. rádicality > ràdicálity). Rather this difference shows that for the suffix -ity the constraint IDENT(S) is dominated by a constraint which requires pwords to end in a dactylic foot. In English, the most common type of allomorphy is truncation. Consonant-initial suffixes are not associated with any phonological effects.

\section{CONSTRAINTS ON ENGLISH WORD FORMATION13}

\subsection{The constraint ${ }^{\prime *}$ CLASH $^{\prime}$}

The undesirability of adjacent stressed syllables is expressed by the following constraint: 14 
The constraint in (10) is manifested by the instability of * CLASH violations. Historically, stress clashes within pwords in English tend to be eliminated by leftward stress shift (cf. (11a)), or, if that is not a possibility, by stress deletion (cf. (11b)). The shaftless arrow denotes historical sound change.
(11) a. demónstràte > démonstràte recógnìze > récognìze altérnàte $>$ álternàte
b. móbìle > móbile dándrùff $>$ dándruff ábdòmen > ábdomen

In word formation potential ${ }^{*}$ CLASH violations arise whenever a stressed suffix attaches to a stem with final stress. As is shown by comparing the phonologically similar suffixes -eer, -ese, and -ee there are several ways to resolve the resulting conflict. For the suffix -eer stress clashes are generally avoided by restricting suffixation to words ending in an unstressed syllable (cf. the native coinages in (12a)). As a result, there exists a systematic gap for words with final stress as in (12b), including monosyllabic words as in (12c):
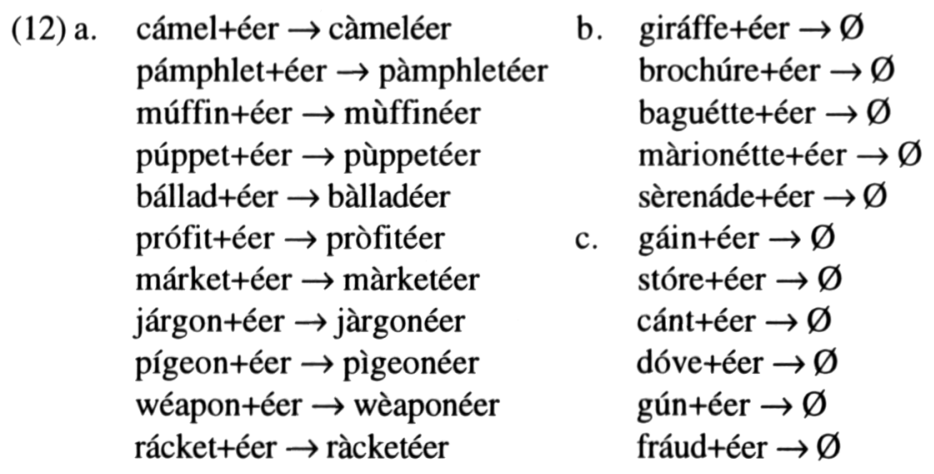

The claim that words with final stress do not undergo -eer suffixation does not preclude the existence of nouns ending in -eer which have cognates with final stress like those in (13a). Crucially, all of those nouns were borrowed into English as is shown in (13b) and are therefore not relevant for the description of native word formation:
(13) a. brìgadíer - brigáde còmmandéer - commánd
cashíer - cash
frontíer - front

b. (French brigadier $\rightarrow$ E. brigadier) (Afrikaans kommanderen $\rightarrow \mathrm{E}$. commandeer) (Dutch cassier, French caissier $\rightarrow$ E. cashier) (Old French frontier $\rightarrow$ E. frountier) 
${ }^{*}$ CLASH violations are also systematically avoided in -ese suffixation. However, instead of not attaching to words with final stress the suffix -ese avoids * CLASH violations by sacrificing stress identity as is shown in (14):

$$
\begin{aligned}
& \text { Taiwán+ése } \rightarrow \text { Tàiwanése } \\
& \text { Nepál+ése } \rightarrow \text { Nèpalése }
\end{aligned}
$$$$
\begin{aligned}
& \text { Sudán+ése } \rightarrow \text { Sùdanése } \\
& \text { Vietnám+ése } \rightarrow \text { Viètnamése }
\end{aligned}
$$

The type of allomorphy illustrated in (14) is characteristic for the suffix -ese $e_{1}$, which attaches to names. There is a distinct suffix - ese $e_{2}$, which attaches to nouns and, like the suffix -eer, combines only with words ending in a stressless syllable. Some coinages are listed in (15):

$$
\text { jàrgonése, jòurnalése, compùterése, nòvelése, translàtionése }
$$

The suffix $-e s e_{2}$ thus avoids stress clash by not attaching to words with final stress. In contrast to the stressed suffixes mentioned so far the suffix -ee tolerates ${ }^{*}$ CLASH violations freely. There is no tendency for this suffix to prefer bases which end in a stressless syllable, as is illustrated in $(16 \mathrm{~b}, \mathrm{c})$.

$$
\begin{array}{ccc}
\text { (16) a. cóunsel+ée } \rightarrow \text { còunselée } & \text { b. seléct+ée } \rightarrow \text { selèctée } & \text { c.bríbe+ée } \rightarrow \text { brìbée } \\
\text { abándon+ée } \rightarrow \text { abàndonée } & \text { abúse+ée } \rightarrow \text { abùsée } & \text { dráft+ée } \rightarrow \text { dràftée } \\
\begin{array}{l}
\text { óffer+ée } \rightarrow \text { òfferée } \\
\text { solícit+ée } \rightarrow \text { solìcitée }
\end{array} & \text { invíte+ée } \rightarrow \text { invìtée } & \text { páy+ée } \rightarrow \text { pàyée } \\
\text { arrést+ée } \rightarrow \text { arrèstée } & \text { híre+ée } \rightarrow \text { hìrée }
\end{array}
$$

The observation that the suffixes -eer, -ese $e_{1}$, and -ee differ systematically in how they respond to potential stress clashes indicates differences in constraint ranking. Consider first the suffix -eer, which never attaches to bases with final stress. In Raffelsiefen (1992) I argued that this type of gap reflects a dilemma: potential -eerformations would be either phonologically ill-formed due to stress clash (i.e. * giràfféer) or the stem (i.e. the derived form minus the affix) would differ from the base in the position of the main stress (i.e. girafféer - giráffe). That is, for suffixes with initial stress like -eer attachment to a base with final stress will always violate either *CLASH or IDENT(S).

Consider now the question of how to ensure that no output is preferred to a candidate which violates either ${ }^{*} \mathrm{CLASH}$ or IDENT(S). The approach to gaps proposed by Prince and Smolensky (1993) is to include the input (i.e. a structure in which affixes are unattached) in the candidate set, to posit a constraint 'M-PARSE' which prohibits unattached affixes, and to rank that constraint below the constraints which cause the gap. The constraint M-PARSE is stated as follows in Prince and Smolensky (1993):

\section{M-PARSE}

Morphemes are parsed into morphological constituents. 
The gap illustrated in $(12 b, c)$ is described by the constraint-ranking in tableau (18). The input consists of the affix -eer and a word which satisfies its syntactic subcategorization requirements (i.e. nouns). The phonological representation of the base includes stress, which is crucial for proper evaluation w.r.t. the constraint IDENT(S). The constraint IDENT(S) ranks higher than *CLASH because the sub-optimal candidate giràfféer, which preserves the stress w.r.t. the base giráffe, is generally preferred to the candidate girafféer.

\begin{tabular}{|l|l||l|l|l|}
\hline \multicolumn{2}{|l||}{ d3ərǽf-íyr } & IDENT(S) & *CLASH & M-PARSE \\
\hline \hline & ${\text { (dżrəfiyr })_{\omega}}^{15}$ & $* !$ & & \\
\hline & (dzəræ̀fiyr) $\omega$ & & $* !$ & \\
\hline$\sqrt{ }$ & dzərǽf-1́yr & & & $* !$ \\
\hline
\end{tabular}

For words with final stress such as giraffe, the non-affixed candidate is optimal, because it is the only candidate which satisfies both IDENT(S) and * CLASH ${ }^{16}$ As a result there is a gap. For other words there is always a candidate which satisfies both IDENT(S) and ${ }^{*} \mathrm{CLASH}$, which means that a noun can be coined:

(19)

\begin{tabular}{|l|l||l|l|l|}
\hline \multicolumn{2}{|l||}{ kǽməl-1́yr } & IDENT(S) & *CLASH & M-PARSE \\
\hline \hline & (kæ̀məliyr $)_{\omega}$ & & & \\
\hline & kǽməl-1́yr & & & $* !$ \\
\hline
\end{tabular}

Note that 'gap-causing' dilemmas cannot arise due to phonological constraints or identity constraints alone, but require that both types of constraints dominate M-PARSE. The phonological constraint causing such a gap would be violated as a result of affixation. The identity constraint requires identity in surface forms (cf. section 7).

For the suffix - ese $_{1}$, both M-PARSE and *CLASH dominate IDENT(S). This ranking accounts for the fact that for this suffix there are neither clash-related gaps nor ${ }^{*}$ CLASH -violations as is shown in (20). 17 
(20)

\begin{tabular}{|l|l||l|l|l|}
\hline \multicolumn{2}{|l||}{ taywán-1́yz } & M-PARSE & *CLASH & IDENT(S) \\
\hline \hline$\sqrt{ }$ & (tàywoníyz) $\omega$ & & $\vdots$ & $*$ \\
\hline & (taywàníyz) $\omega$ & & $* !$ & \\
\hline & taywán-íyz & $* !$ & $\vdots$ & \\
\hline
\end{tabular}

The suffix $-e e$ is similar to the suffix $-e s e_{1}$ in that there are no clash-related gaps and it is similar to the suffix -eer in that it does not allow for stress-shift. It differs from both -ese $e_{1}$ and -eer in that ${ }^{*} \mathrm{CLASH}$-violations are allowed. These observations can be expressed by ranking both M-PARSE and IDENT(S) higher than ${ }^{*} \mathrm{CLASH}$ as is shown in (21):

(21)

\begin{tabular}{|c|c|c|c|c|}
\hline \multicolumn{2}{|c|}{ əsáyn-1́y } & M-PARSE & IDENT(S) & $*_{\mathrm{CLASH}}$ \\
\hline$\sqrt{ }$ & $($ əsàyn íy) $\omega$ & & & $*$ \\
\hline & $\left(\right.$ æ̀səníy) ${ }_{\omega}$ & & $* !$ & \\
\hline & əsáyn-íy & $* !$ & & \\
\hline
\end{tabular}

The suffixes -ee, -ese $e_{1}$, and -eer illustrate the three types of phonological effects in affixation presented in (9). The suffix -ee is the only English suffix which allows for *CLASH - violations thereby giving rise to non-canonical sound patterns. The suffix - ese $_{1}$ is the only suffix for which ${ }^{*} \mathrm{CLASH}$ ranks above IDENT(S) thereby giving rise to allomorphy. All other stressed suffixes follow the pattern of the suffix -eer in that they avoid * CLASH violations by not attaching to words with final stress with the result that there are gaps. The verb-forming suffix -ize, for example, generally resists attachment to nouns or adjectives with word-final stress as is shown by the gap in $(22 \mathrm{a}): 18$
(22) a. corrúpt+íze $\rightarrow \varnothing$
obscéne+íze $\rightarrow \varnothing$
políte + íze $\rightarrow \varnothing$
ápt+íze $\rightarrow \varnothing$
cálm+íze $\rightarrow \varnothing$
bóld+íze $\rightarrow \varnothing$
b. rándom+íze $\rightarrow$ rándomìze
fóreign+íze $\rightarrow$ fóreignìze
rúral+íze $\rightarrow$ rúralìze
ítem+íze $\rightarrow$ ítemìze
líon+íze $\rightarrow$ líonìze
mártyr+íze $\rightarrow$ mártyrìze


The claim that suffixing -ize to the adjective apt would be ungrammatical due to a stress clash (i.e. *áptize) is perfectly consistent with the existence of verbs like báptize, cápsize, or fránchise, which are loan words. In fact, it is conceivable that -ize suffixation like áptize should be considered ungrammatical even if verbs like báptize were to represent the prevailing stress pattern in English. ${ }^{19}$ This is because phonological restrictions in word-formation are affix-specific and are in principle independent of the restrictions which characterize the language as a whole. The theory does however forbid the existence of suffixes with initial stress which attach only to stems with final stress. This is because there is no universal constraint which eliminates precisely the candidates which do not have a stress clash (cf. section 10).

The claim that a description of the conditions on affixation should be confined to native coinages is also supported by the properties of -ation suffixation. The cognates in (23a) might give the impression that the suffix -ation attaches to iambic bases thereby contradicting the claim that ${ }^{*} \mathrm{CLASH}$ dominates IDENTS(S) only for the suffix - ese :

(23) a.

$$
\begin{aligned}
& \text { èxplanátion - expláin } \\
& \text { pèrturbátion - pertúrb } \\
& \text { ìnspirátion - inspíre } \\
& \text { prèservátion - presérve } \\
& \text { èxpirátion - expíre } \\
& \text { àdorátion - adóre } \\
& \text { òbscuration - obscúre } \\
& \text { ìnvitátion - invíte } \\
& \text { àdaptátion - adápt } \\
& \text { cònsultátion - consúlt }
\end{aligned}
$$

$$
\begin{array}{ll}
\text { b. } & \text { remáin+átion } \rightarrow \varnothing \\
& \text { distúrb+átion } \rightarrow \varnothing \\
& \text { desíre+átion } \rightarrow \varnothing \\
& \text { desérve+átion } \rightarrow \varnothing \\
& \text { retíre+átion } \rightarrow \varnothing \\
& \text { ignóre+átion } \rightarrow \varnothing \\
& \text { secúre+átion } \rightarrow \emptyset \\
& \text { delíght+átion } \rightarrow \varnothing \\
\text { adópt+átion } \rightarrow \varnothing \\
\text { insúlt+átion } \rightarrow \varnothing
\end{array}
$$

However, the systematic gap illustrated in (23b) indicates that the suffix -ation may not attach to iambic verbs in English. ${ }^{20}$ In fact, acording to the OED, all nouns in -ation which are etymologically related to iambic verbs in English are borrowings (e.g. Latin explanation-em $>$ Engl. explanation, Latin perturbation-em $>$ Old French perturbacion $>$ Engl. perturbation, etc.). ${ }^{21}$ In English, -ation suffixation is gener-ally confined to specific 'productivity niches', i.e. verbs ending in -ate or in the suffix -ize. ${ }^{22}$ Sporadically, the suffix also applies to verbs which end in a stressless syllable. Some examples are given in (24):

$$
\begin{aligned}
& \text { bóther+átion } \rightarrow \text { bòtherátion } \\
& \text { elícit+átion } \rightarrow \text { elìcitátion } \\
& \text { báckward+átion } \rightarrow \text { bàckwardátion } \\
& \text { páttern+átion } \rightarrow \text { pàtternátion }
\end{aligned}
$$

The constraint ranking in (25), which has also been established for the stressed suffixes -eer and -ize, accounts for the unacceptability of the formations in (23b) while 
allowing for the examples in (24):23

(25)

\begin{tabular}{|l|l||l|l|l|}
\hline \multicolumn{2}{|l||}{ rəméyn-éyšən } & IDENT(S) & *CLASH & M-PARSE \\
\hline \hline & (rèmənéyšən) $\omega$ & $* !$ & & \\
\hline & (rəmèynéyšən) $\omega$ & & $* !$ & \\
\hline$\sqrt{ }$ & rəméyn-éyšən & & & $*$ \\
\hline
\end{tabular}

The fact that -ation attaches to stems ending in a stressless syllable far less productively than for example the suffix -ize might be because -ize subcategorizes for nouns and adjectives, which typically end in a stressless syllable, whereas -ation subcategorizes for verbs, which predominantly end in a stressed syllable. As a result the set of words which serve as a base for wellformed -ize suffixation is much larger, allowing that suffix to 'gain momentum', whereas the productivity of the suffix -ation is stifled. 24

It can be concluded then that for native formations in English IDENT(S) generally dominates ${ }^{*} \mathrm{CLASH}$. This domination is so complete that the existence of scores of related loanwords like expláin and èxplanátion, which suggest the opposite ranking, fails to cause learners to rerank the constraints associated with the suffix -ation. Significantly, the only suffix for which ${ }^{*}$ CLASH ranks higher than IDENT(S), i.e. the suffix $-e s e_{1}$, attaches only to names. Additional evidence which indicates the exceptional status of name-based affixation will be discussed below.

While most stressed vowel-initial suffixes are sensitive to stress clash, consonant-initial suffixes never are. Some examples are given in (26):

(26) -líke gódlìke, dréamlìke, péacòcklìke

-wíse édgewìse, clóckwìse, léngthwìse

-fóld twófòld, thréefòld, fóurfòld

-hóod chíldhòod, fálsehòod, adúlthòod

-móst léftmòst, tópmòst, óutmòst

The analysis of the insensitivity of consonant-initial suffixes to prosodic restrictions is discussed in section 6 .

\subsection{The constraint ' $* L_{i} L_{i}{ }^{\prime}$}

The undesirability of identical liquids within the pword is expressed by the following constraint: 
The occurrence of identical liquids is prohibited. Domain: pword

In historical English phonology, ${ }^{*} \mathrm{~L}_{\mathrm{i}} \mathrm{L}_{\mathrm{i}}$-violations are often eliminated, especially if they both occur in coda position (cf. Luick 1964: 1020ff, 1071). Satisfaction of ${ }^{*} \mathrm{~L}_{\mathrm{i}} \mathrm{L}_{\mathrm{i}}$ is achieved either by deleting one of the liquids (cf. (28a) (cf. Kenyon and Knott 1953: xlvi25) or by substituting one liquid by another sonorant (cf. (28b,c)) ('Dial.' means 'dialectal form'):26

(28) a. $\quad$ su/r/prise $>$ su/Ø/prise (cf. su/r/vive)

gove $/ \mathrm{r} /$ nor $>$ gove $/ \varnothing /$ nor $($ cf. gove $/ \mathrm{r} / \mathrm{n}$ )

cate/r/pillar > cate/Ø/pillar (cf. cate/r/)

b. Dial. little $>$ nittle

Dial. syllable $>$ sinable

c. marbre $>$ marble (cf.German Marmor)

purpre $>$ purple (cf. German purpur)

orer $>$ laurel (cf. German Lorbeer)

turtur $>$ turtle

Dial. murmur $>$ murmel

The constraint ${ }^{*} \mathrm{~L}_{\mathrm{i}} \mathrm{L}_{\mathrm{i}}$ is also obeyed in the phonotactics of English verbs as is illustrated in (29):27

$$
\begin{aligned}
& \text { grumble }(* \text { grumber, } * \text { glumble }) \\
& \text { splinter }(* \text { sprinter, *splintle }) \\
& \text { rattle }(* \text { ratter, } * \text { lattle })
\end{aligned}
$$

In English word formation the constraint ${ }^{*} \mathrm{~L}_{\mathrm{i}} \mathrm{L}_{\mathrm{i}}$ is generally satisfied by both the nominal and the adjectival suffix - $a l$, albeit in different ways. The nominal suffix -al avoids ${ }^{*} \mathrm{~L}_{\mathrm{i}} \mathrm{L}_{\mathrm{i}}$-violations by not attaching to verbs which include the liquid $l$. Examples for gaps are listed in (30). All examples satisfy the syntactic and prosodic restrictions on -al suffixation so that alternative explanations for their ungrammaticality can be ruled out.

$$
\text { (30) a. *XVl+al } \quad \begin{aligned}
& * \text { appéalal, *annúlal, *exhálal, *assáilal, *revéalal, } \\
& \\
& \text { *instálal, *aváilal,*beguílal, *compélal, *compílal, } \\
& \\
& \text { *concéalal, *condólal, *consólal, *contrólal, *curtáilal, } \\
& \\
& \text { *deráilal, *entáilal, *distílal, *enrólal, *excélal, *fulfíllal, } \\
& \text { *inhálal, *instíllal, *propélal, *preváilal, *rebélal, } \\
& \text { *recállal, *repélal, *revéalal, *retáilal } \\
& \text { *insúltal, *invólval, *absólval, *assáultal, *consúltal, } \\
& \text { *dissólval, *engúlfal, *evólval, *exáltal, *rebúildal, } \\
& \text { *repúlsal, *resólval, *resúltal, *revóltal, *withhóldal }
\end{aligned}
$$




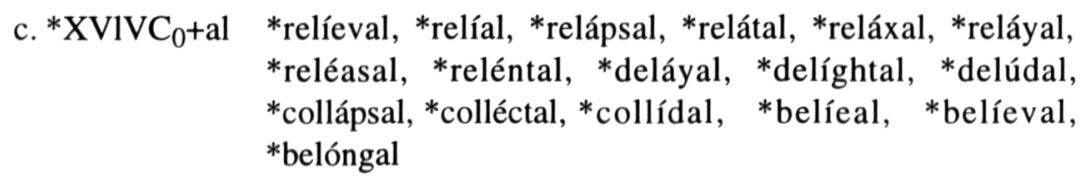

The gap illustrated in (30) can be explained only with reference to output forms. Within a description in terms of prosodic subcategorization frames the correlation between the $l$ in the suffix, the avoidance of stems which include $l$, and the general evidence in support of the constraint ${ }^{*} \mathrm{~L}_{\mathrm{i}} \mathrm{L}_{\mathrm{i}}$ illustrated in (28), (29) would appear to be coincidental.

The four cases in which - al suffixation does violate the constraint $* \mathrm{~L}_{\mathrm{i}} \mathrm{L}_{\mathrm{i}}$ add further support to the claim that the gap in (30) can be explained only with reference to output forms. Significantly, these exceptions are systematic in that one of the liquids does not by itself constitute a syllable node but rather forms part of a complex onset. 28 The term 'syllable node' refers to the constituents onset, nucleus, rhyme, and coda.

$$
\text { disclosal, supplial, declinal, implial }
$$

This suggests that -al suffixation obeys a restricted version of the constraint ${ }^{*} \mathrm{~L}_{\mathrm{i}} \mathrm{L}_{\mathrm{i}}$, which is stated in (32):

$$
\begin{aligned}
& * \mathrm{~L}_{\mathrm{i}} \mathrm{L}_{\mathrm{i}}{ }^{\prime} \\
& \text { Identical syllable nodes consisting of liquids are prohibited. }
\end{aligned}
$$

The constraint ${ }^{*} \mathrm{~L}_{\mathrm{i}} \mathrm{L}_{\mathrm{i}}{ }^{\prime}$ differs from ${ }^{*} \mathrm{~L}_{\mathrm{i}} \mathrm{L}_{\mathrm{i}}$ in that it requires reference to syllabified output forms. That is, the evaluation of candidates depends on the question of whether or not liquids constitute part of complex syllable nodes in the output (e.g. $\sqrt{ }$ dis.clo.sal versus $*$ in.sul.tal). The question of whether liquids are part of complex syllable nodes in the input (e.g. in.sult, in.volve, etc.) is irrelevant for their evaluation.

To conclude, the gap in (30) is adequately described by ranking the constraint ${ }^{*} \mathrm{~L}_{\mathrm{i}} \mathrm{L}_{\mathrm{i}}{ }^{\prime}$ and the constraint IDENT, which requires identity between a candidate and the segmental and metrical structure of the base plus the affix, higher than M-PARSE as is shown in (33). The ranking between the two dominating constraints is motivated by the observation that violations of IDENT are even worse than are violations of ${ }^{*} \mathrm{~L}_{\mathrm{i}} \mathrm{L}_{\mathrm{i}}{ }^{\prime}$. 
(33)

\begin{tabular}{|l|l||l|l|l|}
\hline \multicolumn{2}{|l||}{ əpíyl-əl } & IDENT & $* \mathrm{~L}_{\mathrm{i}} \mathrm{L}_{\mathrm{i}}{ }^{\prime}$ & M-PARSE \\
\hline \hline & oṕ́ynəl & $* !$ & & \\
\hline & əpíyləl & & $* !$ & \\
\hline$\sqrt{ }$ & əpíyl-əl & & & $*$ \\
\hline
\end{tabular}

Consider next the adjectival suffix -al, which satisfies the constraint ${ }^{*} \mathrm{~L}_{\mathrm{i}} \mathrm{L}_{\mathrm{i}}{ }^{\prime}$ not by causing gaps but by violating an identity constraint. Specifically, the liquid in the suffix must not be identical as is shown by the native coinages in (34):
(34) a. mole+al $\rightarrow$ molar $\sim$ molal corolla+al $\rightarrow$ corollar enamel+al $\rightarrow$ enamelar arteriole $+\mathrm{al} \rightarrow$ arteriolar fibrilla + al $\rightarrow$ fibrillar protocol+al $\rightarrow$ protocolar
b. lobule+al $\rightarrow$ lobular nodule + al $\rightarrow$ nodular spherule + al $\rightarrow$ spherular sporule+al $\rightarrow$ sporular zonule + al $\rightarrow$ zonular aedicule + al $\rightarrow$ aedicular

The rule of allomorphy illustrated in (34) has been adopted on the basis of Latinate loans whose stem includes an $l$ such as polar, lunar, familiar, etc. versus loans whose stem includes no $l$ like rational, parental, general and is mostly applied to scientific words. If both liquids are within the same syllable the rule is quite productive. However, as is usually the case with rules of allomorphy in English, true productivity is found only w.r.t. words with a specific ending, in particular nouns ending in -ule (cf. (34b)). In other cases, the rule applies only sporadically which gives rise to variations as is shown in (35):29

$$
\begin{aligned}
& \text { (35) a. } \quad \text { vulva }+ \text { al } \rightarrow \text { vulvar } \sim \text { vulval }{ }^{30} \text { b. column }+a l \rightarrow \text { columnar } \sim \text { columnal } \\
& \text { alga+al } \rightarrow \text { algal } \\
& \text { lava }+ \text { al } \rightarrow \text { laval } \quad \text { dialect }+ \text { al } \rightarrow \text { dialectal }
\end{aligned}
$$

The data in (34), (35) indicate that an even more restricted version of the constraint ${ }^{*} \mathrm{~L}_{\mathrm{i}} \mathrm{L}_{\mathrm{i}}$ is needed to account for the differences between the nominal and the adjectival suffix - al. That is, for the adjectival suffix - al the domain of the constraint is the syllable, not the pword. For both suffixes the constraint against identical liquids is violated only if each liquid constitutes a syllable node. That is, the rule of allomorphy never applies in English if one of the liquids is part of a complex syllable node as shown in (36):31 
(36)

$$
\begin{aligned}
& \text { clause }+ \text { al } \rightarrow \text { clausal (*clausar) } \\
& \text { climate }+ \text { al } \rightarrow \text { climatal }(* \text { climatar }) \\
& \text { cyclic }+ \text { al } \rightarrow \text { cyclical }(* \text { cyclicar }) \\
& \text { inflection }+ \text { al } \rightarrow \text { inflectional }(* \text { inflectionar }) \\
& \text { fluid }+ \text { al } \rightarrow \text { fluidal }(* \text { fluidar }) \\
& \text { glott }+ \text { al } \rightarrow \text { glottal }(* \text { glottar })
\end{aligned}
$$

The data in (34) indicate that for the adjectival suffix -al the constraints IDENT(STEM), which requires the segments in the derived word to be identical to the corresponding segments in the base, ${ }^{*} \mathrm{~L}_{\mathrm{i}} \mathrm{L}_{\mathrm{i}}$ ', and M-PARSE dominate the constraint IDENT(AFFIX), which requires the output affix to be identical to the corresponding input. Since violations of the constraint IDENT(AFFIX) must be both minimal and structurepreserving (cf. section 7) the $l$ is substituted by $r$, which differs only in the feature [ \pm lateral]. ${ }^{32}$ For speakers who prefer coinages like molal to molar IDENT(AFFIX) dominates ${ }^{*} \mathrm{~L}_{\mathrm{i}} \mathrm{L}_{\mathrm{i}}{ }^{\prime}$. For all speakers, the ranking of the identity constraints, ${ }^{*} \mathrm{~L}_{\mathrm{i}} \mathrm{L}_{\mathrm{i}}{ }^{\prime}$, and M-PARSE differ for the nominal and the adjectival suffix -al. The need to associate these homophonous suffixes with different constraint rankings is further supported by the fact that the nominal suffix -al combines only with iambic words whereas the adjectival suffix has no such restrictions. Also the nominal suffix does not allow truncation of any stem material whereas the adjectival suffix requires truncation under certain conditions.

Not all vowel-initial suffixes show $* \mathrm{~L}_{\mathrm{i}} \mathrm{L}_{\mathrm{i}}$-related effects. The agentive suffix $-e r$, for example, is entirely insensitive to that constraint:

murderer, hearer, bearer, chatterer, lecturer, hirer, careerer

Consonant-initial suffixes like -less, -let, -like and -ful are never sensitive to $* \mathrm{~L}_{\mathrm{i}} \mathrm{L}_{\mathrm{i}}$. Some examples for attested native formations are given in (38):

(38) -less goalless, wheelless, muscleless, titleless, lifeless, landless, pollenless

-let altarlet, lakelet, lamplet, leaflet, leglet, scalelet, looplet

-like lifelike, fellowlike, lionlike, ladylike, snaillike

-ful lawful, loathful, doleful, frolicful, guileful

\subsection{Additional dissimilatory constraints}

In addition to the general constraint against syllable nodes consisting of identical liquids there are constraints against identical syllable nodes in specific syllable positions as is shown in (39) ('O' = onset, ' $\mathrm{N}$ ' = nucleus, 'C' = coda, 'S' = segment). The domain of each constraint is the pword. Irrelevant structure is left unspecified. 
(39) a. SHELL 33

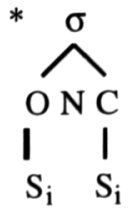

b. ${ }^{*} \mathrm{ONS}_{\mathrm{i}} \mathrm{ONS}_{\mathrm{i}}$

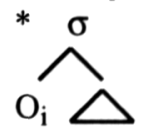

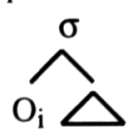

c. ${ }^{*} \mathrm{CODA}_{\mathrm{i}} \mathrm{CODA}_{\mathrm{i}}$

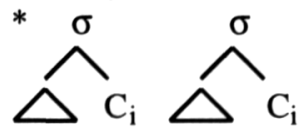

To obey the constraint SHELL, which prohibits syllables for which the nucleus is flanked by identical segments, the generally very productive suffix -ish never attaches to stems ending in the fricative š. Examples for gaps are given in (40b):

$$
\begin{aligned}
& \text { (40) a. } \text { shéep+ish } \rightarrow \text { shéepish } \\
& \text { fármer+ish } \rightarrow \text { fármerish } \\
& \text { vínegar+ish } \rightarrow \text { vínegarish } \\
& \text { cánnibal+ish } \rightarrow \text { cánnibalish }
\end{aligned}
$$
b. físh+ish $\rightarrow \varnothing$$$
\text { squísh }+ \text { ish } \rightarrow \varnothing
$$$$
\text { músh+ish } \rightarrow \varnothing
$$$$
\text { rúbbish+ish } \rightarrow \varnothing
$$

The occurrence of syllables like shish, shash in actual English words (cf. hashish, shashlik) does not affect the evaluation of potential -ish suffixation, which must satisfy the constraint SHELL (cf. the unacceptability of * fishish). The gap in (40b) is described by the constraint ranking in (41). The constraint IDENT(C) requires all consonants in the derived word to correspond to identical consonants in the base. The

\begin{tabular}{|c|c|c|c|c|}
\hline \multicolumn{2}{|c|}{ fIŠ-IS } & IDENT(C) & SHELL & M-PARSE \\
\hline & fittrs & $* !$ & & \\
\hline & fı̆̌šs & & $* !$ & \\
\hline$\sqrt{ }$ & fĭ̌s-IS̆ & & & * \\
\hline
\end{tabular}
ranking between IDENT(C) and SHELL accounts for preferences among the sub-optimal candidates in question.

(41)

The suffix - ous is similar to the suffix -ish in that IDENT(C) and SHELL dominate MPARSE. Words like *biasous are accordingly not potential -ous suffixation, in spite of the widespread occurrence of similar SHELL-violations in actual words (cf. basis, census, emphasis, etc.). ${ }^{34}$
(42) a. flávor+ous $\rightarrow$ flávorous tréason+ous $\rightarrow$ tréasonous vítamin+ous $\rightarrow$ vitáminous únison+ous $\rightarrow$ unísonous
b. bías+ous $\rightarrow \varnothing$ átlas+ous $\rightarrow \varnothing$ ménace+ous $\rightarrow \varnothing$ láttice+ous $\rightarrow \varnothing$


While exhibiting the same ranking among the constraints IDENT(C), SHELL, and MPARSE, the suffixes -ish and -ous differ w.r.t. the ranking of other constraints. Native coinages such as vínegarish based on vínegar versus carnívorous based on cárnivòre show that the constraint which requires a dactylic foot to be aligned to the right edge of prosodic words dominates IDENT(S) for the suffix -ous, but not for the suffix -ish.

Additional suffixes for which IDENT(C) and SHELL dominate M-PARSE are shown in (43). 35 The examples in (43c) show that similar SHELL-violations occur among actual words.

(43) a. pístol+éer $\rightarrow$ pìstoléer

$$
\begin{array}{llc}
\begin{array}{l}
\text { pístol+éer } \rightarrow \text { pìstoléer } \\
\text { munítion+éer } \rightarrow \text { munìtionéer }
\end{array} & \begin{array}{c}
\text { b. revólver+éer } \rightarrow \emptyset \\
\text { mórtar+éer } \rightarrow \emptyset
\end{array} & \text { c. (cf. career, rear) } \\
\begin{array}{l}
\text { kítchen+étte } \rightarrow \text { kìtchenétte } \\
\text { tówel+étte } \rightarrow \text { tòwelétte }
\end{array} & \begin{array}{l}
\text { clóset+étte } \rightarrow \emptyset \\
\text { cárpet+étte } \rightarrow \emptyset
\end{array} & \begin{array}{r}
\text { (cf.quartette, } \\
\text { quintette) }
\end{array} \\
\begin{array}{l}
\text { shórt+age } \rightarrow \text { shórtage } \\
\text { cléave+age } \rightarrow \text { cléavage }
\end{array} & \begin{array}{l}
\text { lárge+age } \rightarrow \emptyset \\
\text { wédge+age } \rightarrow \emptyset
\end{array} & \text { (cf. judge) }
\end{array}
$$$$
\text { mórtar+éer } \rightarrow \varnothing
$$$$
\text { clóset+étte } \rightarrow \varnothing
$$$$
\text { cárpet+étte } \rightarrow \varnothing
$$$$
\text { (cf.quartette, }
$$

$$
\begin{aligned}
& \text { lárge }+ \text { age } \rightarrow \emptyset \\
& \text { wédge }+ \text { age } \rightarrow \varnothing
\end{aligned} \quad \text { (cf. judge) }
$$

The constraint against identical syllable onsets in adjacent syllables (cf. (39b)) is manifested in the haplology in words like Englaland $>$ England, eightetene $>$ eighteen (cf. Luick 1964: 1071). This constraint also plays a role in systematic gaps in English -ity suffixation. It is no coincidence that -ity never attaches to stems ending in $-t$. The unacceptability of the nouns in (44) is due neither to violations of subcategorizational requirements (i.e. all nouns are based on Latinate adjectives) nor to blocking by lexicalized nominalizations.
(44) a. *acútity, *complétity, *òbsolétity, *remótity, *discréetity, *conténtity, *occúltity, *fáintity, *quáintity, *pàramóuntity, *exáctity, *abrúptity, *áptity, *inéptity, *corrúptity, *diréctity, *compáctity, *abstráctity, *intáctity, *corréctity, *stríctity, *dèrelíctity, *distínctity, *succínctity, *extínctity, *defúnctity, *disjúnctity
b. **covértity, **sèparátity, **affèctionátity, **quiétity, **pèrmanéntity, $* *$ perféctity, $* *$ consìderátity

The unacceptability of the nonce words in (44) is all the more remarkable in view of the fact that quite a few nouns end in -tity (cf. entity, identity, quantity, sanctity). The only case where -ity has been suffixed to a stem ending in - $t$ in English is the noun vastity, where, crucially, suffixation does not result in adjacent identical onsets. The observation that the nouns in (44b) are particularly bad is presumably due to the fact that $\mathrm{ONS}_{\mathrm{i}} \mathrm{ONS}_{\mathrm{i}}$ violations are compounded by IDENT(S) violations (cf. section 7).

The fact that -ity never attaches to adjectives ending in -did as in (45a) is also expected since these are precisely the cases where -ity suffixation would cause adjacent 
identical onsets (cf. the native coinages in (45b)):

(45) a. candid+ity $\rightarrow \varnothing$ (*candidity) b. trepídity, squalídity, morbídity, splendid+ity $\rightarrow \emptyset(*$ splendidity) rabídity, turgídity, pallídity, sordid+ity $\rightarrow \varnothing$ (*sordidity) vapídity, torrídity, florídity, vivídity, fervídity

The suffix -ify is like the suffix -ity in that $\mathrm{ONS}_{\mathrm{i}} \mathrm{ONS}_{\mathrm{i}}$-violations are avoided by gaps. Some examples are listed in (46):

(46) a. *déafify, *tóughify, *stíffify, *béefify, *róughify

b. $* *$ sheríffify, $* *$ plaintíffify, $* *$ dandrúffify

The suffix -ify is also like the suffix -ity in that formations become even less acceptable if they involve additional IDENT(s) violations (cf. (46b)). Such violations are allowed only for adjectives ending in -id (cf. humídify, rigídify, fluídify, etc.). ${ }^{36}$

The suffixes -ee and -ize differ from -ity and -ify in that $\mathrm{ONS}_{\mathrm{i}} \mathrm{ONS}_{\mathrm{i}}$-violations are avoided not by gaps, but by 'truncation' of the word-final VC-string. ${ }^{37}$ The examples in (47) show that truncation, which constitutes a violation of 'complete identity', applies only if necessary to prevent $\mathrm{ONS}_{\mathrm{i}} \mathrm{ONS}_{\mathrm{i}}$-violations. ${ }^{38}$

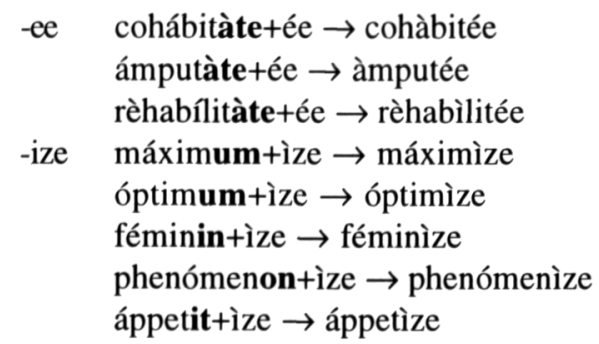

délegàte+ée $\rightarrow$ dèlegàtée
cónsecràte+ée $\rightarrow$ cònsecràtée
éducàte+ée $\rightarrow$ èducàtée
rádium+ìze $\rightarrow$ rádiumìze
vácuum+ìze $\rightarrow$ vácuumìze
másculin+ìze $\rightarrow$ másculinìze
skéleton+ìze $\rightarrow$ skéletonìze
párasit+ìze $\rightarrow$ párasitìze

Truncation, however, is never resorted to as a means to avoid $\mathrm{ONS}_{\mathrm{i}} \mathrm{ONS}_{\mathrm{i}}$-violations if the remaining stem consists of less than a disyllabic foot. In that case there is a systematic gap: 39

$$
\begin{aligned}
& \text {-ee rótàte+ee } \rightarrow \varnothing \quad(* \text { ròtée, } * \text { ròtàtée }) \quad \text { cóllàte+ée } \rightarrow \text { còllàtée } \\
& \text { díctàte+ee } \rightarrow \varnothing \text { (*dìctée, *dìctàtée) lócàte+ée } \rightarrow \text { lòcàtée } \\
& \text { mútàte+ee } \rightarrow \emptyset(* \text { mùtée, *mùtàtée) } \text { mándàte+ée } \rightarrow \text { màndàtée } \\
& \text {-ize Híttìte+ìze } \rightarrow \varnothing \text { (*Híttìze, *Híttitìze) Sémìte+ìze } \rightarrow \text { Sémitìze } \\
& \text { línen+ìze } \rightarrow \varnothing \quad\left({ }^{*} \text { línìze, *línenìze }\right) \quad \text { cótton+ìze } \rightarrow \text { cóttonìze } \\
& \text { hórror+ìze } \rightarrow \varnothing \text { (*hórrìze, *hórrorìze) vígor+ìze } \rightarrow \text { vígorìze } \\
& \text { Lénin+ìze } \rightarrow \emptyset \text { (*Lénìze, *Léninìze) Stálin+ìze } \rightarrow \text { Stálinìze } \\
& \text { cándid+ìze } \rightarrow \emptyset \text { (*cándìze, *ándidìze) líquid+ìze } \rightarrow \text { líquidìze }
\end{aligned}
$$

The unacceptable -ee-formations *ròtée, ${ }^{*}$ dictée, etc. violate a constraint IDENT (BINFT), which requires the last binary foot in the base to be preserved in the derived 
word. The ill-formedness of forms like *Hittize, * línize, etc. is already accounted for by the dominance of ${ }^{*}$ CLASH over M-PARSE for the suffix -ize. 40 Additional examples are given in (49):

(49) a. émphasis+ize $\rightarrow$ émphasìze epénthesis+ize $\rightarrow$ epénthesìze sýnthesis+ize $\rightarrow$ sýnthesìze hypóthesis+ize $\rightarrow$ hypóthesize b. cathársis+ize $\rightarrow \varnothing$ (*cathársìze) ellípsis+ize $\rightarrow \varnothing \quad$ (*ellípsìze) crísis+ize $\rightarrow \varnothing \quad(*$ crísìze $)$ scépsis + ize $\rightarrow \varnothing \quad$ (*scépsìze $)$

The suffixation in (49a) versus the gaps in (49b) are described by the ranking in (50):

\begin{tabular}{|c|c|c|c|c|c|}
\hline \multicolumn{2}{|c|}{ émfəsis-áyz } & IDENT(S) & $\mathrm{ONS}_{\mathrm{i}} \mathrm{ONS}_{\mathrm{i}}$ & ${ }^{*}$ CLASH & M-PARSE \\
\hline & 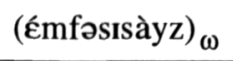 & & $* !$ & & \\
\hline \multirow[t]{3}{*}{$\sqrt{ }$} & $(\varepsilon ́ m f ə s a ̀ y z) \omega$ & & & & \\
\hline & $(\text { émfàyz })_{\omega}$ & & & $* !$ & \\
\hline & émfəsis-áyz & & & & $* !$ \\
\hline \multicolumn{2}{|c|}{ kə日ársıs-áyz } & & & & \\
\hline & 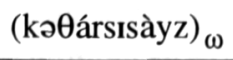 & & $* !$ & & \\
\hline & $($ kəӨársàyz) $\omega$ & & & $* !$ & \\
\hline & 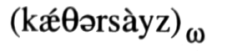 & $* !$ & & & \\
\hline$\sqrt{ }$ & kəӨársıs-áyz & & & & * \\
\hline
\end{tabular}

In view of the dependency of $\mathrm{ONS}_{\mathrm{i}} \mathrm{ONS}_{\mathrm{i}}$-violations on the segmental structure of both the stem and the suffix, the phonological effects presented here can be explained only by an output-oriented approach. Since each suffix is associated with an individual constraint-ranking there could exist vowel-initial suffixes which freely violate the constraint $\mathrm{ONS}_{\mathrm{i}} \mathrm{ONS}_{\mathrm{i}}$. An example is -able suffixation as is shown in (51):

(51) -able bribable, describable, absorbable, perturbable

Assuming that the constraint $\mathrm{ONS}_{\mathrm{i}} \mathrm{ONS}_{\mathrm{i}}$ is similar to the other phonological constraints considered here in that it applies within the pword and that consonantinitial suffixes are not integrated into the pword of the stem one can expect that there are no $\mathrm{ONS}_{\mathrm{i}} \mathrm{ONS}_{\mathrm{i}}$ related effects in consonant-initial suffixation. There is in fact no evidence for such effects as is illustrated in (52): 


$\begin{array}{ll}\text {-ness } & \text { boniness, neatness, newness, tininess } \\ \text {-less } & \text { fellowless, pollenless, lifeless, landless } \\ \text {-ment } & \text { commitment, blemishment, movement, enamourment } \\ \text {-ship } & \text { marshalship, relationship, ushership } \\ \text {-ful } & \text { fearful, forceful, faithful } \\ \text {-ly } & \text { lowly, lovely, lonely, lightly, lively }\end{array}$

\subsection{Sonority constraints}

The suffix -en differs from the vowel-initial suffixes considered above in that it attaches only to monosyllabic stems which end in an obstruent (cf. Marchand 1969: 214). ${ }^{41}$ Examples for gaps are given in $(53 \mathrm{~b}, \mathrm{c}) .{ }^{42}$

$$
\begin{array}{ccc}
\text { (53) a. tough+en } \rightarrow \text { tóughen } & \text { b. éarnest+en } \rightarrow \varnothing & \text { c. warm+en } \rightarrow \varnothing \\
\text { weak+en } \rightarrow \text { wéaken } & \text { módest+en } \rightarrow \varnothing & \text { shy+en } \rightarrow \varnothing \\
\text { crisp+en } \rightarrow \text { críspen } & \text { básic+en } \rightarrow \varnothing & \text { full+en } \rightarrow \varnothing \\
\text { brisk+en } \rightarrow \text { brísken } & \text { stúbborn+en } \rightarrow \varnothing & \text { dear+en } \rightarrow \varnothing \\
\text { swift+en } \rightarrow \text { swíften } & \text { vívid+en } \rightarrow \varnothing & \text { clean+en } \rightarrow \varnothing
\end{array}
$$

From the perspective of an output-oriented approach the gap in (53b) reflects a requirement for pwords consisting solely of a trochaic foot. The gap in (53c) reflects the restriction on the sonority of onsets stated in (54):

$$
\begin{aligned}
& \text { ONS SON } \\
& \text { Syllable onsets must have sonority at least as low as a fricative. }
\end{aligned}
$$

The sonority restriction on syllable onsets referred to in constraint (54) is marked by the shaded area in table (55). Note that the allowable segments must belong to adjacent columns in the sonority hierarchy such that the rightmost column, which contains the least sonorous segments, is included. 43

(55) increasing sonority $\leftarrow$ $\rightarrow$ decreasing sonority

\begin{tabular}{|l|l|l|l|l|l|l|}
\hline Vowels & Glides & $\mathrm{r}$ & 1 & Nasals & Fricatives & Stops \\
\hline
\end{tabular}

According to Vennemann (1988:13ff) onsets are the more preferred the lower their sonority whereas codas are the more preferred the higher their sonority. ${ }^{44}$ The constraint in (54) is one of a family of low sonority constraints for onsets which differ in the upper limit for the sonority. Crucially, a restriction to low sonority consonants is natural when referring to onsets, but not to codas. Therefore a description of the gap in (53c) in terms of a phonological subcategorization frame for the suffix -en is inadequate since it would imply that the requirement for consonants with low so- 
nority pertained to the coda. By contrast, on an output-oriented approach the sonority restriction in question applies to onsets and can accordingly be described in terms of universal constraints. The tableau in (56) shows the evaluation of -en suffixation based on the adjectives warm and tough:45

(56) a.

\begin{tabular}{|l|l||l|l|l|}
\hline \multicolumn{2}{|l||}{ worm-ən } & IDENT & ONS SON & M-PARSE \\
\hline \hline & (wor.bən) & $* !$ & & \\
\hline & (wor.mən) & & $* !$ & \\
\hline & worm-ən & & & $*$ \\
\hline
\end{tabular}

b.

\begin{tabular}{|c|c|c|c|}
\hline$t \wedge f-ə n$ & IDENT & ONS SON & M-PARSE \\
\hline (tর̌́fən) & & & \\
\hline tıf-əon & & & $* !$ \\
\hline
\end{tabular}

\subsection{The constraint $* V V$}

To avoid violations of the constraint $* \mathrm{Vv}$, which prohibits hiatus or onsetless syllables, certain suffixes never attach to vowel-final stems. One such suffix is -eer, as is illustrated by the gap in $(57 \mathrm{~b})$ :
(57) a. músket+éer $\rightarrow$ mùsketéer
wéapon+éer $\rightarrow$ wèaponéer
b. bazóoka+éer $\rightarrow \varnothing$
járgon+éer $\rightarrow$ jàrgonéer
torpédo+éer $\rightarrow \varnothing$
slógan+éer $\rightarrow$ slòganéer
língo+éer $\rightarrow \varnothing$
mótto+éer $\rightarrow \varnothing$

The phonologically similar suffix -ee fails to attach only if the vowels to be combined are identical:
(58) a. réscue+ée $\rightarrow$ rèscuée
b. frée+ee $\rightarrow \varnothing$
dráw+ée $\rightarrow$ dràwée
sée+ee $\rightarrow \varnothing$
páy+ée $\rightarrow$ pàyée
cárry+ée $\rightarrow \varnothing$
ínterview+ée $\rightarrow$ ìnterviewée
píty+ée $\rightarrow \varnothing$
bórrow+ée $\rightarrow$ bòrrowée
énvy+ée $\rightarrow \varnothing$ 


$$
\begin{array}{ll}
\text { emplóy+ée } \rightarrow \text { emplòyée } & \text { cópy+ée } \rightarrow \varnothing \\
\text { thrów+ée } \rightarrow \text { thròwée } & \text { accómpany+ée } \rightarrow \varnothing
\end{array}
$$

The suffix - ese $e_{1}$ differs from both -eer and -ee in that violations of *vV are avoided at the expense of the identity violations manifested as 'vowel deletion' or ' $n$-epenthesis', depending on the moraic structure of the base. 46
(59) a. Chína+ése $\rightarrow$ Chìnése
Málta+ése $\rightarrow$ Màltése
b. Jáva+ése $\rightarrow$ Jàvanése
Búrma+ése $\rightarrow$ Bùrmése
Báli+ése $\rightarrow$ Bàlinése
Góa+ése $\rightarrow$ Gòanése

In accordance with the description of the the suffix - ese $e_{1}$ above the data in (59) indicate a high ranking of M-PARSE and phonological wellformedness constraints (e.g. ${ }^{*}$ CLASH and ${ }^{*} \mathrm{VV}$ ) w.r.t. identity constraints. In English, $-e s e_{1}$ is the only suffix for which the phonological constraint $* V V$ is satisfied through 'epenthesis', i.e. a violation of the identity constraint which requires that each segment in the derived form must correspond to a segment in the base or the affix. The suffix -ize differs from all suffixes considered so far in that it causes truncation only if the resulting form has no stress clash. Some examples are shown in (60):
(60) a. mémory+ìze $\rightarrow$ mémorìze
jéopardy+ìze $\rightarrow$ jéopardìze
b. sílly+ìze $\rightarrow \varnothing$ (*síllìze)
énvy $\rightarrow \varnothing$ (*énvìze)
apóstrophe+ìze $\rightarrow$ apóstrophìze
assémbly $\rightarrow \varnothing$ (*assémblìze)
priórity+ìze $\rightarrow$ prióritìze
attórney $\rightarrow \emptyset$ (*attórnìze)

The suffixes -er, -able and -ish freely violate *vv as is illustrated in (61):

(61) carrier, hurrier, copier, envier, dallier, lobbyer, rallier variable, marriable, buriable, pitiable, leviable, enviable

babyish, shabbyish, dandyish, rowdyish, fogyish, monkeyish

\subsection{Some constraints which play no role in English suffixation}

The cognates in (62a) are often cited in support of the claim that suffixes like -al, -ous, -ify, and -ity belong to a specific class of suffixes which trigger Trisyllabic Laxing. The cognates in (62b) are sometimes subsumed under that same rule (cf. Chomsky and Halle 1968; Myers 1987):

$$
\begin{array}{ll}
\text { (62) a. } & \mathrm{n}[æ] \text { tural - n[ey]ture } \\
& \mathrm{f}[æ] \text { bulous - f[ey]ble } \\
& \mathrm{v}[\mathrm{I}] \text { lify - v[ay]le } \\
& \text { prof[æ]nity - prof[ey]ne }
\end{array}
$$
b. $\mathrm{m}[\mathrm{I}] \mathrm{mic}-\mathrm{m}[\mathrm{ay}] \mathrm{me}$
$\mathrm{t}[\mathrm{a}]$ nic $-\mathrm{t}[\mathrm{ow}] \mathrm{ne}$
st[æ]tic - st[ey]te
rabb[I]nic - rabb[ay]

Vowel laxness in (62b) could also be subsumed under the 'Arab rule', which forbids 
long vowels if the following syllable is unstressed and has a noncoronal coda consonant (cf. Fidelholtz 1967).

The alternations in (62a) are due to a constraint on vowel length which also accounts for the absence of underived words like ${ }^{*} c[$ ey]mera (cf. $c[æ]$ mera), *[iy]lefant (cf. $[\varepsilon]$ lefant). Because of the 'Arab rule' there are no words like $* h$ [ey]voc (cf. $h[æ] v o c$ ), * sh[iy]riff (cf. $s h[\varepsilon]$ riff), *s[ay]rup (cf. $s[\mathbf{I}]$ rup). However, there is no evidence that these constraints play a role in word-formation. They neither cause gaps nor 'allomorphy' as is illustrated by the native coinages in (63):

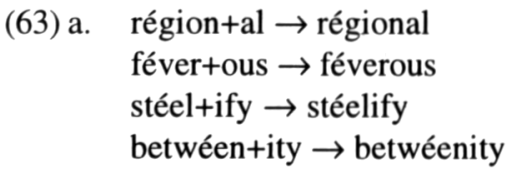
b. base+ic $\rightarrow$ básic
amóeba+ic $\rightarrow$ amóebic
gnome+ic $\rightarrow$ gnómic
phoneme+ic $\rightarrow$ phonémic

The reader may convince herself that the derived words are entirely unacceptable when pronounced with laxed vowels. The words in (62), which obey the constraints on vowel laxness in question, differ from the derived words in (63) in that they are loan words.

\section{PHONOLOGICAL EFFECTS ASSOCIATED WITH CONSONANT INITIAL SUFFIXES}

Are there counterexamples to the claim that consonant-initial suffixation never shows phonological effects? Consider words like insécticide, humánifỳ, lóngitùde which are sometimes analysed as being derived by consonant-initial suffixes (i.e. cide, fy, tude) (cf. Fudge 1984; Burzio 199447). The analysis of the suffixes in question as consonant-initial appears to be motivated primarily on etymological grounds. The observation that in native derivations those suffixes regularly appear with an 'insert' vowel $i$ indicates that they have been reanalysed as vowel-initial suffixes in English as is illustrated in (64). 48 Phonological effects like satisfaction of the constraint $\mathrm{ONS}_{\mathrm{i}} \mathrm{ONS}_{\mathrm{i}}$ in -icide and -ify suffixation are therefore to be expected.

$$
\begin{aligned}
& \text { weed+icide } \rightarrow \text { weedicide } \\
& \text { brute+ify } \rightarrow \text { brutify } \\
& \text { lax }+ \text { itude } \rightarrow \text { laxitude }
\end{aligned}
$$

Consider next the examples in (65), which seem to contradict the claim that consonant-initial suffixes do not cause allomorphy ('<' stands for 'historically goes back to').

$$
\begin{aligned}
& \text { w[í]sdom (< wíse+dom) } \\
& \text { bús[Ø]ness (< búsy+ness) }
\end{aligned}
$$




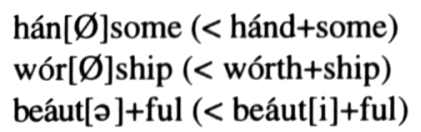

That the phonological alternations in (65) are not properties of the suffixes can be inferred from the fact that these suffixes do not typically cause stem modification. 49 Instead these effects reflect the historical fusion of stems and suffixes into one pword shown in (66a). This process is especially common among words with high token frequency. The historical fusion of two pwords into a single pword with concomitant phonological changes can also be observed in compounds as is shown in (66b): 50
(66) a. (wíse) $)_{\omega}$ dom $>$ (wísdom) $\omega$ (búsy) $)_{\omega}$ ness $>$ (búsiness) ${ }_{\omega}$ (hánd) ${ }_{\omega}$ some $>$ (hándsome $)_{\omega}$ (wórth) $)_{\omega}$ ship $>$ (wórship) $\omega$ (beáuti) ${ }_{\omega}$ ful $>$ (beáutiful $)_{\omega}$
b. (cúp) $)_{\omega}$ (bòard $)_{\omega}>$ (cúpboard) $\omega$ (néck) $)_{\omega}(\text { làce })_{\omega}>$ (nécklace $)_{\omega}$

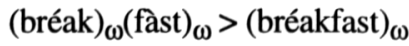 (shéep) $)_{\omega}(\text { hèrd })_{\omega}>$ (shépherd $)_{\omega}$ (fóre) $)_{\omega}(\text { hèad })_{\omega}>$ (fórehead $)_{\omega}$

In contrast to the historically fused suffixations in (65), which affect only individual words, suffixes with an initial glide are systematically integrated into the pword of the stem.

(67) a. compóse+ure $\rightarrow$ (compósure $)_{\omega}$ b.

$\begin{array}{ll}\text { expóse+ure } \rightarrow \text { (expósure })_{\omega} & \text { hóme+ward } \rightarrow \text { (hómeward })_{\omega} \\ \text { depárt+ure } \rightarrow \text { (depárture })_{\omega} & \text { Gód+ward } \rightarrow(\text { Gódward })_{\omega} \\ \text { rápt+ure } \rightarrow \text { (rápture })_{\omega} & \text { stréet+ward } \rightarrow(\text { stréetward })_{\omega} \\ \text { eráse+ure } \rightarrow(\text { erásure })_{\omega} & \text { wáy+ward } \rightarrow(\text { wáyward })_{\omega}\end{array}$

The suffix - ure exhibits two types of phonological effects. It attaches only to stems which end in an alveolar obstruent and merges with this obstruent into a (structure-preserving) palatal fricative or affricate which functions as onset (e.g. $\operatorname{era}[\mathrm{s}]+[\mathrm{yər}] \rightarrow \operatorname{era}[$. šor] era[.žər], compo[z] $+[\mathrm{yər}] \rightarrow \operatorname{compo}[$. žər] $\operatorname{rap}[\mathrm{t}]+[\mathrm{yər}] \rightarrow$ $\operatorname{rap}[. c ̌ r]]) .51$ The allomorphy thus agrees with the evidence from syllabification which indicates that the stem and the suffix constitute one pword. 52 The native suffix -ward exhibits no phonological effects except for the fact that almost all suffixations consist of trochees. 53 The evidence from syllabification may seem to indicate that -ward is not integrated into the pword of the stem because stem-final $[\mathrm{k}],[\mathrm{g}],[\mathrm{t}],[\mathrm{d}],[\mathrm{s}]$, and $[\theta]$ appear in coda position although these consonants can precede the velar glide in onset position (e.g. queen, guacamole, tweed, dwarf, swing, thwart). However, the apparent LOI violations do not necessarily indicate intervening pword boundaries because there is evidence that the complex onsets in question are disallowed in schwa syllables in English. The evidence includes both historical cluster simplifications (e.g. an [sw]er $>$ an $[\mathrm{s}]$ er, li $[\mathrm{kw}]$ or $>$ li $[\mathrm{k}]$ or, con $[\mathrm{kw}]$ er $>\operatorname{con}[\mathrm{k}] e r)^{54}$ and the synchronic syllable structure of simplexes (e.g E[d.w]ard, aw[k.w]ard). 55 While syllabification is accordingly inconclusive when determining the prosodic structure of -ward 
suffixation there is one argument from stress which suggests that -ward is integrated into the pword of the stem. According to the OED, the suffix is pronounced [wəd] when attached to a monosyllabic word but [wo:d] when an unstressed syllable precedes. This type of dependency does not hold for any other consonant-initial suffix and is characteristic for stress reduction within pwords (e.g. áltar vs. séminàr, hóstile vs. júvenile, áuburn vs. tácitùrn). It appears then that the suffixes -ure and -ward are integrated into the pword of the stem although they do not start with a vowel.

The suffix -ry is similar to the glide-initial suffixes but unlike other consonantinitial suffixes in that it too is integrated into the pword of the stem. The evidence for this claim is that the syllabification of the stem-final consonants is determined by the LOI as is shown by the examples in (68):

$$
\begin{aligned}
& \text { húsband+ry } \rightarrow \text { husban.dry } \\
& \text { bígot+ry } \rightarrow \text { bigo.try } \\
& \text { pédant+ry } \rightarrow \text { pedan.try } \\
& \text { bándit+ry } \rightarrow \text { bandi.try } \\
& \text { rócket+ry } \rightarrow \text { rocke.try }
\end{aligned}
$$

In addition the suffix attaches only to stems which end in a trochee:

$$
\text { ráscalry, rívalry, révelry, rávenry, rócketry, párrotry, }
$$
fórestry, sávagery, ímagery, freemásonry

As a result, -ry suffixation always yields dactyls. This output restriction highlights the relatedness between the suffix -ry and the vowel-initial suffix -ery, which attaches only to stems with final stress and thereby also yields outputs ending in dactyls. Some examples are given in (70): 56

$$
\begin{aligned}
& \text { snóbbery, róbbery, bríbery, fórgery, físhery, fóolery, máchinery, } \\
& \text { scénery, gréenery, wínery, buffóonery, clównery, brávery, prúdery, } \\
& \text { midwífery }
\end{aligned}
$$

Assuming that all nouns in (68)-(70) are derived by the same suffix one could maintain the generalization that only vowel- and glide-initial suffixes show phonological effects. That is, one could posit a single suffix -ery, which requires outputs which end in a dactyl but does not require the preservation of its initial schwa. The distribution of -ry/-ery thus parallels the distribution of the suffix -encel-ency, which is also determined by the requirement that the output form ends in a dactyl (cf. the native coinages belligerence, sálience versus cúrrency, látency). ${ }^{57}$ At any rate, ry/-ery suffixation supports the claim that the domain of phonological effects in word formation is identical to the domain of syllabification.

Consider finally the adverbial suffix $-l y$, which in some cases shows schwa-zero alternations. Significantly, in those cases the suffix is integrated into the pword of 
the stem as is shown by the syllabification of the derived words. Integration of this suffix into the pword of the stem is not one of its regular properties as is shown by the LOI-violations in (71):
(71) a. sim.ply (cf. simp[ə]l)
possi.bly (cf. possib[ə]l)
b. deep.ly
superb.ly
understanda.bly (cf. understandab[ə]l) thick.ly

In some cases the alternations illustrated in (71a) may be related to the irregular historical schwa loss and degemination in words like fforgivenness in that the forms originally contained two identical consonants preceded by schwa. However, in general those alternations appear to be determined by orthographic rather than phonological structure. That is, alternations obtain only if the final rhyme in the base is spelled $<\mathrm{le}>$, which includes all words derived by the suffix -able. Otherwise there is no allomorphy as is shown in (72b) (cf. also roy[ə]lly, radic[ə]lly, verb[ə]lly, etc).

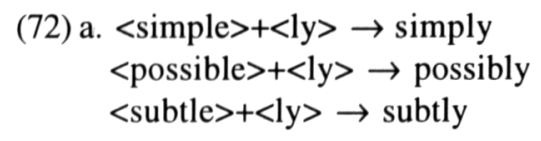
b. $<$ cruel $>+<$ ly $>\rightarrow$ cruelly $<$ level $>+<$ ly $>\rightarrow$ levelly $<$ novel $>+<$ ly $>\rightarrow$ novelly

The alternations in (71a) can thus be explained as the result of conventions which pertain to the relation between written and spoken forms.

Consider next the alternations in (73), which according to Wiese (1996) show that the suffixes -ly and -ness trigger schwa insertion to satisfy their preference for stem-final trochees.
(73) a. distress[ə]dly - distress[Ø]d amaz[ə]dly - amaz[Ø]d perplex[ə]dly - perplex[Ø]d prepar[ə]dly - prepar[Ø]d fix[ə]dly - fix[Ø]d
b. distress[ə]dness - distress[Ø]d amaz[ə]dness - amaz[Ø]d perplex[ə]dness - perplex[Ø]d prepar[ə]dness - prepar[Ø]d fix[ə]dness - fix $[\varnothing] \mathrm{d}$

In contrast to Wiese I will argue that those alternations do not indicate phonological constraints on ly- or -ness suffixation but rather show that the phonological conditions for word formation can be obscured by historical sound changes. That is, the alternations in (73) result from the historical schwa loss in the adjectives 58 which occurred after the derived forms came into existence. 59 The claim that -ness and -ly suffixation prefer stem-final trochees is contradicted by the tendency to replace the adjectival stems with schwa by their schwa-less successors. Consider the examples in (74), which Walker (1826) transcribed with a schwa, which according to the OED has since been lost. $60 \mathrm{By}$ contrast, there are no examples of historical schwa epenthesis in -ness or -ly suffixation.

$$
\text { deform[ə]dly }>\text { deform[Ø]dly blear[ə]dness }>\text { blear[Ø]dness }
$$




$$
\begin{aligned}
& \text { resign[ə]dly }>\text { resign[Ø]dly } \\
& \text { restrain[ə]dly }>\text { restrain[Ø]dly } \\
& \text { confus[ə]dly }>\text { confus[Ø]dly } \\
& \text { resolv[ə]dly }>\text { resolv[Ø]dly }
\end{aligned}
$$

\author{
compos[ə]dness $>$ compos[Ø]dness \\ diffus[ə]dness $>$ diffus[Ø]dness \\ confus[ə]dness $>$ confus $[\varnothing]$ dness \\ reserv[ə]dness $>$ reserv[ $[$ ]dness
}

The changes in (74) show that schwa loss in the adjectives has not led English learners to associate phonological constraints with the suffixes -ly and -ness, but rather has resulted in the fossilization of the derived forms which retained the schwa. Fossilization is manifested not only in the instability illustrated in (74) but also in various idiosyncracies (e.g.prepar[ə]dness is military jargon, mark[ə]dness is linguistics jargon). ${ }^{61}$ I conclude then contrary to Wiese that the suffixes -ly and -ness neither historically nor synchronically exhibit a preference for stems ending in trochees. The schwa-zero alternations in (73) are represented most adequately by listing those words in the lexicon without positing metrical constraints on the suffixes.

Perhaps the clearest case of phonological sensitivity exhibited by a consonantinitial suffix is the tendency for the adverbial suffix -ly to resist attachment to adjectives ending in -ly. Yet, the OED lists 24 counterexamples to this generalizations. A few are listed in (75):62

$$
\text { chillily, cleanlily, friendlily, holily, jollily }
$$

Other suffixes with initial $l$ show no phonological effects (e.g. -let, -less, -ling). The same holds for suffixes whose first consonant is less sonorous.

Granting that the status of the suffix -ly is unclear I conclude that only glideinitial suffixes and the suffix -ry/-ery exhibit regular phonological effects. ${ }^{63}$ The fact that the initial segments in these suffixes are highly sonorous is unlikely to be coincidental in view of the fact that onsets are the less preferred the more sonorous they are (cf. section 4.4). A formal analysis of this observation is discussed in section 6. Significantly, neither -ure, -ward, nor -ry/-ery suffixation contradict the generalization that phonological effects in word formation are found only within the domain of syllabification (i.e. the pword).

\section{THE PROSODIC STRUCTURE OF SUFFIXED WORDS}

In the preceding section I have presented evidence that only vowel-initial and glideinitial suffixes induce phonological effects. Assuming that in English the pword is the domain for morphophonological constraints this observation is accounted for by the integration of those suffixes, but not consonant-initial suffixes, into the pword of the stem. Compare the acceptable -like suffixations in (76) with the unacceptable -ize-formations. The attested -ize-formations are cited to show that the unacceptability of the starred formations is not due to semantic properties. 
$\begin{array}{lll}\text { (76) béelìke } & \text { *stéelìze (cf. copperize) } \\ \text { cówlìke } & * \text { 'ówlìze (cf. vulturize) } \\ \text { fúrlìke } & * \text { gírlìze (cf. womanize) }\end{array}$

The difference in the acceptability of the formations in (76) can be explained with reference to neither segmental, syllabic, nor metrical structure. Instead that difference can be described in terms of a systematic contrast in the prosodic structure of the words. Crucially, the constraint ${ }^{*}$ CLASH would be satisfied in béelike if the consonant-initial suffix were not integrated into the pword of the stem as is shown in $(77): 64$

\begin{tabular}{|l|l||l|}
\hline \multicolumn{2}{|l|}{ biy+layk } & *CLASH \\
\hline \hline \multicolumn{2}{|l|}{$\left(\right.$ bíy) ${ }_{\omega}$ làyk } & \\
\hline \multicolumn{2}{|l|}{ stiyl+ayz } & \\
\hline \hline & (stíylàyz) $\omega$ & $*$ \\
\hline
\end{tabular}

How can the dependence of prosodic structure on the initial segment of the suffix be expressed in terms of constraints? Prince and Smolensky (1993) proposed that this dependency be captured by ranking the constraint ONSET, which prohibits onsetless syllables, higher than certain alignment constraints. Consider the constraint ALIGN SUFFIX, which aligns the left edge of a suffix with the right edge of a pword thereby ensuring that suffixes are not integrated into the pword of their stem:

\section{ALIGN SUFFIX}

Align (Suffix, L, Pword, R)

Assuming that pwords constitute the domain for syllabification the integration of vowel-initial suffixes into the pword of the stem is achieved by ranking ONSET higher than ALIGN SUFFIX. 65

(79) a.

\begin{tabular}{|l|l||l|l|}
\hline \multicolumn{2}{|l||}{ biy+layk } & ONSET & ALIGN SUFFIX \\
\hline \hline$\sqrt{ }$ & (bíy.) $\omega_{\omega}$ làyk & & \\
\hline & (bíy.làyk) $\omega$ & & $* !$ \\
\hline
\end{tabular}


b.

\begin{tabular}{|l|l||l|l|}
\hline \multicolumn{2}{|l||}{$\left(\right.$ stiyl $\omega^{- \text {-ayz }}$} & ONSET & ALIGN SUFFIX \\
\hline \hline$\sqrt{ }$ & $(\text { stíyl. })_{\omega}$ àyz & $* !$ & \\
\hline & $(\text { stíy.làyz })_{\omega}$ & & $*$ \\
\hline
\end{tabular}

To ensure that glide-initial suffixes are also integrated into the pword of the stem the syllable structure constraint which dominates ALIGN SUFFIX is formulated as follows:

\section{ONSET'}

Syllables must have a [+consonantal] onset

The restriction expressed in (80) is similar to the constraint ONS SON in (54) associated with the suffix -en in that it expresses an upper limit on the sonority of onsets (cf. the sonority hierarchy in (55)). It is in fact not entirely clear where that limit is. There are no suffixes with initial $r$ except for the suffix $-r y$, which has been analysed as a variant of the suffix - ery. If - ry were analysed as the basic variant the upper limit on the sonority of onsets in (80) would have to be lowered to exclude the $r$. Crucially, the universal preference for syllable onsets with low sonority implies that the exclusion of $r$ entails the exclusion of glides but not vice versa.

As it stands the constraint ranking in (79) does not account for the general integration of vowel-initial suffixes into the pword of the stem but results in integration only if the stem-final segment could serve as a syllable onset. The prediction would then be that vowel-initial suffixes freely attach to vowel-final bases without inducing allomorphy or gaps, which is clearly incorrect (cf. the constraint $* \mathrm{VV}$ in 4.5). To make the analysis work, suffixes with an inadequate onset must always be integrated into the pword of the stem, whether or not such integration actually supplies the lacking onset. 66

The constraint ranking in (79) does not account for the prosodic structure of consonant-initial suffixes. Assuming that pwords constitute the domain for word stress, vowel reduction in (81) shows that the English suffixes differ from their German cognates in that they are not separate pwords. 67 The fact that vowels have never reduced in English monosyllabic words which used to be homophonous to those suffixes (e.g. mess, bull) follows from the pword status of lexical words.

$$
\begin{array}{ll}
\text { English } & \text { German } \\
\text { [ləs] '-less' } & {[\text { lo:s] '-los' }} \\
\text { [fəl] '-ful' } & {[\text { fol] '-voll' }} \\
\text { [dəm] '-dom' } & {[\text { tu:m] '-tum' }} \\
\text { [nəs] '-ness' } & {[\mathrm{nis}] \text { '-nis' }} \\
\text { [səm] '-some' } & {[\mathrm{za}: \mathrm{m}] \text { '-sam' }} \\
{[\text { mənt] '-ment' }} & {[\text { ment] '-ment' }}
\end{array}
$$


[lət] '-let' [let] '-let'

Vowel reduction in English consonant-initial suffixes is blocked only under certain phonological conditions. In the suffix [hud] -hood (cf. the German cognate [hart] -heit) the vowel fails to reduce due to a constraint against schwa syllables whose onset is [h] ${ }^{68}$ In the suffix -ship the vowel fails to reduce due to the post-vocalic non-coronal obstruent. ${ }^{69}$ Diphthongs fail to reduce (cf. the suffixes -like, -wise $e^{70}$ ) as do long vowels followed by clusters (cf. -fold, - -most). In such cases stress is assigned by weight, and not because those suffixes are pwords. This type of stress differs from the stress assigned to pwords in that it is inherently unstable. The suffix -most is pronounced [məst] in colloquial British English which perhaps indicates that the unreduced variant will eventually disappear in (at least) that variety of English. Prosodically words with consonant-initial suffixes are perhaps best categorized as clitic groups, ${ }^{71}$ where the difference between suffixes with unreduced vowels and those with reduced vowels could be represented as in (82a) versus (82b) ('C' = Clitic group, ' $\Sigma$ ' = Foot). 72

(82) a. American English

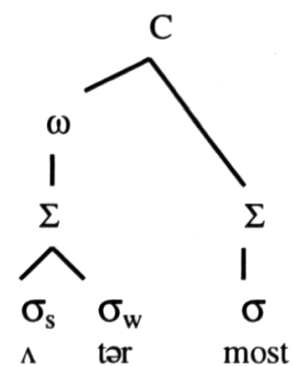

b. Colloquial

British English

The stress on the suffix is unstable because the relevant foot is not dominated by a pword. By contrast, the righthand members of compounds have stable stress since they are dominated by a pword (e.g. (béd) $\omega_{\omega}$ (pòst $)_{\omega}$, (párcel $\left.)_{\omega}(\text { pòst })_{\omega}\right) \cdot{ }^{73}$ Similarly, the stress on vowel-initial suffixes is stable since such suffixes are dominated by pwords as well as is shown by the examples legalize, infantile, Japanese shown in (83).74 Neither English nor German consonant-initial suffixes carry main stress as some vowel-initial suffixes do: 75
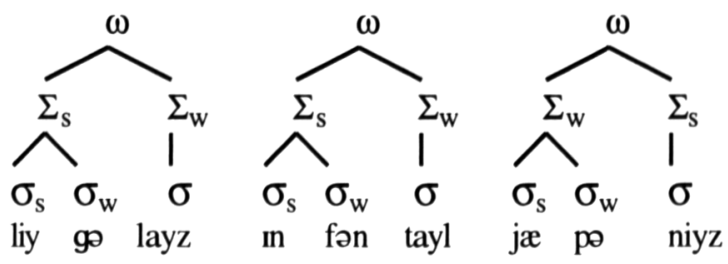
To account for stress neutrality Aronoff and Sridhar (1983) represent the suffix -ize as a clitic, which is not integrated into the pword of the stem, in accordance with their analysis of stress-neutral consonant-initial suffixes. However, the evidence from syllabification shows that this analysis cannot be correct. If the suffix -ize were not integrated into the pword of the stem the stem-final consonant should be ambisyllabic, because of the rule which associates the final consonant of a pword with the following vowel (cf. Kahn 1976). 76 Ambisyllabicity can be easily recognized in American English because of the flapping of coronal stops regardless of the stress on the following vowel. 77 Consider the examples night owl and Pat is shown in (84): 78
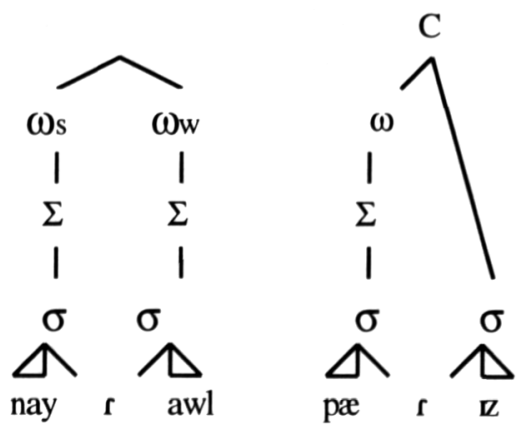

The fact that the stem-final $t$ in -ize suffixation is never flapped shows that the suffix constitutes neither a separate pword, nor a clitic (cf. verbs like alphabe[t]ize, magne[t]ize, puppe $[\mathrm{t}]$ ize). ${ }^{79}$ Rather the suffix -ize is integrated into the pword of the stem as is shown in (83). 80 This analysis is also supported by the fact that the suffix -ize exhibits phonological effects in word formation, in contrast to consonant-initial suffixes.

To summarize, the assumption that only vowel- and glide-initial, but not consonant-initial, suffixes are integrated into the pword of their stem explains the systematic correlation between seemingly unrelated properties concerning syllabification, stress, and morphophonological effects. Specifically, the analysis explains why consonant-initial suffixes tend to undergo vowel reduction, why they form a separate domain for syllabification (cf. the LOI violations in the words in (4)), why they do not induce allomorphy and why they are insensitive to the phonological properties of their base with the result that there are no gaps.

These correlations are not universal. In German many consonant-initial suffixes yield systematic phonological effects although the evidence from both syllabification and stress shows that they are not integrated into the pword of the stem. ${ }^{81}$ The suffix -chen induces truncation of the stem-final schwa syllables $-e$ and $-e n$, but not $-e l$ and 
-er. This suffix, which has an initial palatal fricative, furthermore does not attach to stems which end in a palatal or velar fricative. 82 The general rule of $g$-spirantization in coda position after the vowel $i$ (e.g. Köni[ç] 'king'-Köni[g]e 'kings') fails when the coda in the following syllable includes a velar spirant (e.g. köni[k]li[ç] könig+lich 'kingly'. This rule clearly applies across pword boundaries as it also accounts for the 'blocking' of $g$-spirantization in compounds like Köni[k]rei[ç] 'kingdom' (cf. Drosdowski (ed.) 1990: 75). The suffix -nis does not attach to stems which end in $n$ (cf. by contrast the English formations cleanness, brazenness, etc). The suffix -lein does not attach to stems which end in $-l$ (cf. by contrast the English formations snaillike, vowellike, etc). These examples suggest that in German the pword is not the relevant domain for the dissimilatory constraints in question. 83 Why this systematic difference between English and German exists is unclear.

\section{THE ISSUE OF ABSTRACTNESS}

To explain the observation that certain gaps in word-formation arise to avoid stress clashes it is necessary to refer to the (surface) stress pattern of both the input and the candidates. Specifically, the evaluation of candidate forms w.r.t. the constraint IDENT(S), which requires the stress in the derived form to be identical to the stress on the corresponding syllables in the base, requires reference to the surface representation.

But just how concrete should the phonological representations be to allow one to capture the relevant generalizations? Consider again the gaps due to the constraints which ban identical segments within the phonological word (e.g. ${ }^{*} \mathrm{~L}_{\mathrm{i}} \mathrm{L}_{\mathrm{i}}$, SHELL). In many English dialects liquids or stops have clearly distinct allophones depending on their position within the syllable. Recall that the $t$ is aspirated in syllable-initial position, glottalized in coda position, and flapped when ambisyllabic. Similarly, the $l$ is often vocalized in coda position but not in onset position in British English (cf. Wells 1982: 258ff). As a result on the phonetic level the constraint against identical segments in forms like *acutity, *appealal, *revolvereer, * closetette, etc. is not violated and therefore cannot be invoked to explain their ungrammaticality. Yet, it seems intuitively clear that the various phonetic realizations of stops or liquids in English dialects do not affect the unacceptability of those forms. It appears then that the notion of distinctiveness or structure-preservation is crucial when defining the level of abstractness which is relevant for describing phonological effects in word formation. 84

The notion of distinctiveness is also crucial for describing the restrictions on intensive- $s$ formations in English. As was noted by Stampe (1972), the prefix [s] never attaches to words with an initial voiced stop. The rule is illustrated with examples from Wright's English dialect grammar in (85):85

$$
\begin{array}{ccc}
\text { (85) a. s+voiceless stop } & \text { b. } s+\text { sonorant } & \text { c. }{ }^{*} \text { s+voiced stop } \\
\text { s+clash } \rightarrow \text { sclash } & \text { s+lounge } \rightarrow \text { slounge } & s+\text { bat } \rightarrow \varnothing
\end{array}
$$




$$
\begin{array}{lll}
\text { s+crunch } \rightarrow \text { scrunch } & \text { s+matter } \rightarrow \text { smatter } & \text { s+gush } \rightarrow \varnothing \\
\text { s+plunge } \rightarrow \text { splunge } & \text { s+notch } \rightarrow \text { snotch } & \text { s+dash } \rightarrow \varnothing \\
\text { s+quilt } \rightarrow \text { squilt } & \text { s+rake } \rightarrow \text { srake } & \\
\text { s+trample } \rightarrow \text { strample } & \text { s+wang } \rightarrow \text { swang } &
\end{array}
$$

The dilemma reflected by the gap in (85c) can be described as follows. Any $s$-formation based on a word with an initial voiced stop such as bash would be either phonologically ill-formed (e.g. *[sb]ash) or the stop in the derived word would differ from the corresponding stop in the base regarding the feature voice (e.g. s[p]ash[b]ash). 86 The two relevant constraints are stated below:

(86) a. AGREE VOICE

Obstruent clusters must agree w.r.t. the feature [ \pm voice]. Domain: syllable

b. IDENT(F)

Corresponding consonants must have identical values for distinctive features.

The analysis of the gap in (85c) is illustrated in tableau (87):

(87)

\begin{tabular}{|l|l||l|l|l|}
\hline \multicolumn{2}{|l||}{ s+bæ̌̌ } & AGREE VOICE & IDENT(F) & M-PARSE \\
\hline \hline & sbæ̌̌ & $* !$ & & \\
\hline & spæš & & $* !$ & \\
\hline$\sqrt{ }$ & s-bæš & & & $*$ \\
\hline
\end{tabular}

The constraint ranking in (87) accounts for the acceptability of the attested $s$-prefixations as is illustrated in (88):

\begin{tabular}{|l|l||l|l|l|}
\hline \multicolumn{2}{|l||}{ s+klæš } & AGREE VOICE & IDENT(F) & M-PARSE \\
\hline \hline$\sqrt{ }$ & sklæš & & & \\
\hline & s + klæš & & & $* !$ \\
\hline
\end{tabular}

The point of interest here is that there are clear phonetic differences between the acceptable formations and their respective bases. The corresponding stops in the onsets in (85a) differ with respect to aspiration (e.g. [ $\left.\mathrm{k}^{\mathrm{h}}\right]$ lash versus $s[\mathrm{k}]$ lash) and the corresponding sonorants in the onsets in $(85 \mathrm{~b})$ differ with respect to voicing (e.g. 
[1] ounge versus $s[1]$ ounge). However, neither aspiration nor voicing in sonorants is distinctive in English, so the formations in (85) do not violate identity constraints. It appears then that allophonic features cannot cause gaps or allomorphy. 87

The claim that reference to phonemic representations is not only necessary but sufficient for a description of English morphophonology might seem to be refuted by the coinages in (89):

$$
\begin{array}{lll}
\text { Nix[ə]n+ian } & \rightarrow & \text { Nix[ów]nian } \\
\text { 'Nixon+ian' } & & \text { 'Nixonian' } \\
\text { Sieg[ə]n+ian } & \rightarrow & \text { Sieg[ć]nian } \\
\text { 'Siegen+ian' } & & \text { 'Siegenian' } \\
\text { Jord[ə]n+ian } & \rightarrow & \text { Jord[éy]nian } \\
\text { 'Jordan+ian' } & & \text { 'Jordanian' }
\end{array}
$$

Within classic generative phonology the vowel alternations in (89) are described by positing abstract underlying vowels in the underived words. Such descriptions fail to explain how the coiners of the derived forms in (89) could identify that abstract vowel. In the examples in (89) alternations cannot play a role. Obviously the vowels are inferred from the written representations. It certainly seems plausible that the coiners of the derivations in (89) were literate. The input for word formation in (89) consists accordingly of both a graphemic and a phonemic representation as is illustrated in (90):

$$
\begin{gathered}
<\text { Nixon }>+<\text { ian }> \\
\text { núksən }+ \text { iən }
\end{gathered}
$$

In native word formation the occurrence of full vowel-schwa alternations appears to be largely confined to names (cf. also $N[ə]$ pál-N[غे]palése). While there are many loan words which show such alternations comparable coinages tend to be unacceptable. This indicates a high ranking of the relevant identity constraint w.r.t. M-PARSE for almost all suffixes as is illustrated by the gaps in (91b) (cf. also the examples in (44b)):

$$
\begin{array}{cc}
\text { (91) a. modérnity - módern (cf. F modernité) } & \text { b. wéstern +ity } \rightarrow \emptyset(* \text { westérnity) } \\
\text { oríginal - órigin (cf. L originalis) } & \text { zéppelin+al } \rightarrow \emptyset(* \text { zeppélinal }) \\
\text { persónify - pérson (cf. F personnifier) } & \text { pígeon+ify } \rightarrow \varnothing(* \text { pigeónify) }
\end{array}
$$

Coinages which do involve full vowel-schwa alternations are typically confined to certain endings as is illustrated in (92):

(92) márgin[əl] - màrgin[ǽləti]

géner[əs] - gèner[ásəti]

drínk[əbəl] - drìnk[əb́lləti ] 
Arguably the examples of word formation in (92) are not due to suffixation but rather involve 'correlative patterns' (cf. Marchand 1969). Correlative patterns are inferred on the basis of recognized relations between words as in (93a):

(93) a. Inference of a correlative pattern:

$$
\begin{aligned}
& \operatorname{aud[éyšəs}]_{A}-\operatorname{aud}[æ ́ s ə t i]_{N} \\
& \text { sag[éyšəs] }]_{A}-\operatorname{sag}[\ddot{x} \text { səti }]_{N} \\
& \operatorname{ten}[\text { éyšəs] }]_{\mathrm{A}}-\operatorname{ten}[\text { ǽsəti] }]_{\mathrm{N}} \\
& \therefore \mathrm{X}[\text { éyšəs }]_{\mathrm{A}}-\mathrm{X}[\text { x́sati }]_{\mathrm{N}}
\end{aligned}
$$

b. Application of the pattern in word formation:

Input: nug[éyšəs] $]_{A}$

$\mathrm{X}[\text { éyšəs }]_{\mathrm{A}}-\mathrm{X}[\text { x́sati }]_{\mathrm{N}}$

$\therefore$ nug[éyšəs $]_{\mathrm{A}}-\operatorname{nug}[\text { x́səti }]_{\mathrm{N}}$

The inference of correlative patterns presupposes that learners have recognized relations between words which exhibit alternations in the endings but not in the initial strings. Word formation which is based on correlative patterns involves the instantiation of variables by strings which need not be independent words as is shown in (93b). This type of word formation typically shows complete productivity, which is atypical for derivational morphology.

The claim that the word formation in (93b) is based on the association of specific phonological strings is supported by the observation that nouns which involve slightly different patterns like specious-* ${ }^{*}$ specity or pernicious-*pernicity are unacceptable. The complete productivity of the pattern in (93) compared to the unacceptability of slightly different patterns could not be expressed if the noun in (93b) was derived by -ity suffixation. Instead this contrast in acceptability indicates that speakers do not associate the suffix -ity with phonological effects like vowel laxing, fricative depalatalization, and truncation but rather apply specific correlative patterns in the formation of new words by variable substitution. The application of the correlative pattern $\mathrm{X}[\text { éyšs }]_{\mathrm{A}}-\mathrm{X}[\mathfrak{x} \text { səti }]_{\mathrm{N}}$ in word formation hence overrides the constraints on -ity suffixation. ${ }^{88}$

\section{DIFFERENCES WITH PREVIOUS WORK}

\subsection{Differences with descriptions in terms of affix classes}

In generative descriptions of English morphophonology affixes are typically grouped to account for the putative correlation of properties like those illustrated in (94) (cf. Chomsky and Halle 1968; Siegel 1974; Selkirk 1982):

(94) a.

attach also to stems

trigger stress shifts

trigger segmental adjustments

$\begin{array}{ll}\text { class I } & \text { class II } \\ \text { yes } & \text { no } \\ \text { yes } & \text { no } \\ \text { yes } & \text { no }\end{array}$


b. Class I: -ous, -al, -ity, -ize, ify, ...

Class II -ness, -less, -ful, -hood, ish, ...

The correlations in (94) are generally associated with the origin of the suffixes: class I suffixes are mostly Latinate and class II suffixes are mostly Germanic. However, class membership is an idiosyncratic property of affixes which is not phonologically determined. There is hence no claim that the onset of a suffix plays any role in English morphophonology. Examples to illustrate the correlation of class I properties are given in (95):

\begin{tabular}{|c|c|c|c|}
\hline & $\begin{array}{l}\text { stem-based } \\
\text { heinous }\end{array}$ & $\begin{array}{l}\text { Trisyllabic Laxing } \\
\text { [a]minous (cf. [ow]men) }\end{array}$ & $\begin{array}{l}\text { stress shift } \\
\text { indústrious(cf. índustry) }\end{array}$ \\
\hline & liberal & $\mathrm{n}[\mathfrak{x}]$ tural (cf. $\mathrm{n}[$ ey]ture) & oríginal (cf. órigin) \\
\hline & affinity & s[æ]nity (cf. s[ey]ne) & legálity (cf. (légal) \\
\hline & ostracize & $\mathrm{p}[\mathfrak{x}]$ tronize (cf. $\mathrm{p}[\mathrm{ey}]$ tron) & e (cf. (immún \\
\hline & edify & $\mathrm{m}[\mathrm{a}]$ dify (cf. $\mathrm{m}[\mathrm{ow}] \mathrm{de}$ )per & sónify (cf. pérson) \\
\hline
\end{tabular}

However, when only native word formation and additional phonological effects (notably the sensitivity of affixes to phonological properties of the stem) are taken into account the distinction between the two classes evaporates. First, it is incorrect that Latinate affixes can attach to non-words. Putative stem-based word formation is generally due to the fact that an affixed word, but not its etymological base, has been borrowed. For example, the Old French adjective haïneus, but not its base haïne, was borrowed into English with the result that Modern English heinous lacks a word base. Crucially, the non-existence of the word hein in English implies that the adjective heinous could not have been formed natively.

The characterization of Germanic affixation as word-based is due to the fact that borrowings happen to be exceedingly rare among words derived by Germanic affixes. However, there is a second source of putative stem-based word formation, which also affects natively derived words. That is, occasionally the base of a derived word, but not the derived word itself, becomes obsolete. Some examples from Germanic are wistful-†wist, hapless-†hap, shabby-†shab, uncouth-†couth. In such cases it is also misleading to state that Germanic affixes can exceptionally attach to stems since the words in question were formed before the respective bases became obsolete.

Trisyllabic Laxing plays no role in native word-formation regardless of the origin of the affix (cf. section 4.6.). By contrast, stress-related phonological effects obtain for almost all vowel-initial suffixes. However, no two suffixes show the same effects which is true even for near-homophonous suffixes like -ee, -eer, and -ese or adjectival and nominal -al (cf. sections 4.1, 4.2.). ${ }^{89}$ Consider further the Latinate suffixes -ize and -ify, both of which yield verbs. Verbs derived by the suffix -ize systematically violate the constraint * LAPSE, which prohibits two adjacent unstressed syllables, to satisfy IDENT(S) while the opposite ranking between those constraints obtains for verbs derived by -ify suffixation. Some examples are shown in (96): 
(96)

$$
\begin{array}{ll}
\text { rádical+ìze } \rightarrow \text { rádicalìze } & \text { sólid+ifỳ } \rightarrow \text { * sólidifỳ } \\
\text { hóspital+ìze } \rightarrow \text { hóspitalìze } & \text { pérson+ifỳ } \rightarrow * \text { pérsonifỳ } \\
\text { cháracter+ìze } \rightarrow \text { cháracterìze } & \text { hístory+ifỳ } \rightarrow * \text { hístorifỳ }
\end{array}
$$

The suffixes - al and -ous both show a restriction to maximally ternary final feet (cf. by contrast the suffixes in (7)). However, they differ in that -al freely attaches to monosyllabic stems (cf. (97a)). That is, in terms of output forms the suffix -ous shows a preference for dactyls (cf. (97b)) whereas the suffix -al shows no such preference:

$$
\begin{array}{ll}
\text { (97) a. tide+al } \rightarrow \text { tídal } & \text { b. hill+ous } \rightarrow \varnothing \mathrm{cf} \text {. móuntain+ous } \rightarrow \text { móntainous } \\
\text { tube }+ \text { al } \rightarrow \text { túbal } & \text { creep+ous } \rightarrow \varnothing \mathrm{cf.} \mathrm{tráitor+ous} \rightarrow \text { tráitorous } \\
\text { tribe+al } \rightarrow \text { tríbal } & \text { chill+ous } \rightarrow \varnothing \mathrm{cf} \text {. féver+ous } \rightarrow \text { féverous } \\
\text { globe+al } \rightarrow \text { glóbal } & \text { risk+ous } \rightarrow \varnothing \mathrm{cf} \text {. házard+ous } \rightarrow \text { házardous }
\end{array}
$$

It is hard to see how the range of stress-related effects (i.e. gaps and allomorphy) exhibited by English suffixes can be captured in terms of suffix classes. A partial solution would be to limit reference to affix classes to account for allomorphy (i.e. systematic stress shifts) and to describe gaps in terms of phonological subcategorization frames associated with each affix (cf. Inkelas 1990; Booij and Lieber 1993). However, it is widely accepted now that such an approach fails to reveal the motivation behind phonologically conditioned gaps (cf. Booij 1998 and references therein). The approach advocated here is to associate to each suffix a specific ranking for the constraints IDENT(S), ${ }^{*}$ CLASH, * ${ }^{*}$ APSE, and constraints on foot size. The fact that Germanic suffixes exhibit generally no stress effects follows from the fact that they typically start with a consonant.

Descriptions of English morphonology in terms of affix-classes are inadequate not only in that they fail to capture systematic differences between Latinate suffixes. They also fail to capture similarities between Latinate and Germanic suffixes. The consonant-initial Latinate suffix -ment is similar to all consonant-initial Germanic suffixes in that it exhibits no phonological effects. On the other hand, the vowelinitial Germanic suffixes -en and comparative -er are similar to many vowel-initial Latinate suffixes in that they are sensitive to the metrical structure of their stem. The vowel-initial Germanic suffix -ish is similar to many vowel-initial Latinate suffixes in that it avoids violations of the constraint SHELL. These similarities are expressed by way of associating the suffixes with identical rankings between the constraints in question.

To summarize, descriptions of English morphonology in terms of arbitrary affixclasses fail to capture the generalization that the onset of a suffix determines whether or not it exhibits phonological effects. Those descriptions also fail to express the generalization that in English phonological effects in word formation are found only within the domain of syllabification. Both generalizations are expressed by integrating suffixes with insufficient onsets into the pword of the stem and by specifying 
the pword as the domain for phonological constraints in word formation.

\subsection{Differences with Burzio's (1994) analysis}

Burzio's (1994) description of stress patterns in English suffixation differs from other descriptions in that all suffixes are metrified. In this approach, even the suffixes -ness, -less, and -ment, which are generally classified as stress-neutral, are systematically integrated into the foot structure of any stem whose phonological structure allows for the integration of an additional syllable. The stems in question end either in a stressed syllable (cf. (98a)) or in trochaic foot optionally closed by a sonorant or $s$ (cf. (98b)). If those suffixes are not integrable they are parsed as a separate foot as shown in (98c). A final null vowel is posited to satisfy foot binarity:
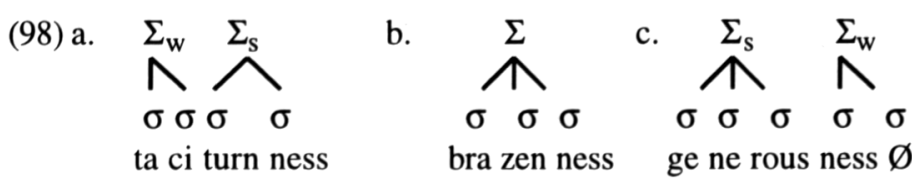

bra zen ness ge ne rous ness $\varnothing$

Burzio does not refer to pwords. However, on the assumption that consonantinitial suffixes are not integrated into the pword of the stem the foot structures in (98a) and (98b) are ruled out by the Prosodic Hierarchy. Instead the structures are those shown in (99), which account not only for the stress patterns but also for syllabification 90 and for the occurrence of word-internal geminates like tacitur[n.n]ess, braze[n.n]ess.

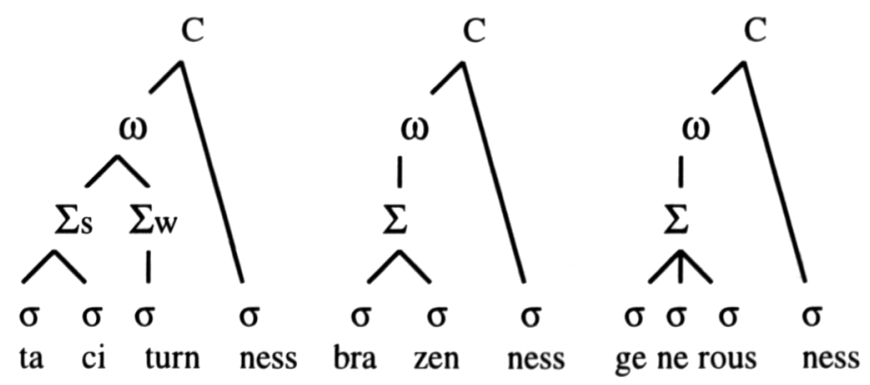

The descriptions of stress in (98) and (99) differ in two respects. According to Burzio's description the suffix constitutes a separate foot and is consequently stressed when it attaches to a stem which ends in a dactyl or a trochee which ends in an obstruent other than $s$. He does not discuss the phonological evidence for this claim but to my knowledge the suffix is invariably unstressed as expressed in (99). A second difference concerns relative prominence relations in words like taciturnness, which show remetrification as a result of -ness suffixation according to Burzio. The evidence he cites are patterns like árbitràry-àrbitráriness, ímitàtive-ìmitátiveness, 
which he claims obtain "for many American speakers" (Burzio 1994: 240). It is unclear if such stress shifts always involve adjectives ending in -àry and -àtive and if they correlate with a reversal of relative prominence relations in other clitic structures. At least the relative prominence pattern in (98a) appears to be generally unacceptable.

Burzio's description differs from mine not only in that all suffixes are metrified but also in that stress effects are claimed to be predictable on the basis of the phonological form of the suffix. While such a description would go beyond the one I have proposed he achieves this aim only at the expense of considerable abstractness. Consider again the distinct stress effects triggered by the monosyllabic suffixes in (100a) versus (100b), which I have attributed to the suffix-initial segment:

$$
\begin{aligned}
& \text { (100)a. accómpany+ment } \rightarrow \text { accómpanyment } \\
& \begin{array}{l}
\text { génerous }+ \text { ness } \rightarrow \text { génerousness } \\
\text { cháracter+less } \rightarrow \text { cháracterless }
\end{array} \\
& \text { báchelor+hood } \rightarrow \text { báchelorhood }
\end{aligned}
$$
b. gélatin+ous $\rightarrow$ gelátinous médicin + al $\rightarrow$ medícinal

According to Burzio, stress neutrality in (100a) is due not to the presence of a syllable onset but rather to the structure of the rhyme. Specifically, he claims that -ment, but not -al or -ous, can constitute a separate foot due to the final cluster. To account for the stress neutrality of the remaining cases he claims that the suffixes -less and -ness contain final geminates and the suffix -hood contains a long vowel whereas the suffixes - al and -ous contain only short segments. There is no independent evidence for those claims. Is it a coincidence that all suffixes for which abstract length is postulated to account for stress neutrality start with a consonant?

Consider next Burzio's account of some systematic differences between vowelinitial suffixes. The stress-neutrality of the suffix -ize (cf. pérsonal+ize $\rightarrow$ pérsonalize ) compared to the stress shift in -ify suffixation (pérson+ifỳ $\rightarrow$ persónifỳ) is accounted for by claiming that -ize, but not $-f y$, constitutes a separate foot. However, there is no discernible difference between the stress on those suffixes. Similarly, stress neutrality in -acy-suffixation (cf. áccurate $+a c y \rightarrow$ áccuracy) compared to stress shifts in -ity suffixations (légal+ity $\rightarrow$ legálity) is accounted for by positing the metrically distinct lexical representations ity) and a)cy for those suffixes, where the right parenthesis marks the right foot boundary. Systematic differences between the suffixes - $i c$ and - $a l$ are accounted for by positing a null vowel before the right foot boundary in the lexical representation of the suffix -ic (i.e. $i c \varnothing$ ) versus $a$ )l). There is no independent phonological evidence for any of these representations which calls into question their explanatory power. 91 What prevents the linguist from positing long segments, null vowels, or foot boundaries to account for different stress effects? ${ }^{92}$ What is to be gained by such a description especially with regard to a theory of possible phonological effects in word formation?

Consider finally Burzio's account of gaps, which is similar to mine in that gaps result when suffixation would violate either a constraint on metrical wellformedness 
or a constraint which requires stress identity w.r.t. the base. Specifically he states that suffixes which require stress neutrality but cannot constitute a separate foot attach only to stems that can integrate them as a syllable. The suffixes which are allegedly subject to this restriction include the consonant-initial suffixes -ful, -dom, and -some (Burzio 1994: 259, 273ff), which are claimed to differ from-less, -ness and -hood in that they cannot constitute a separate foot.

While it is true that there are very few cases of -ful, -dom, or -some suffixation based on dactylic or trochaic stems which end in a consonant other than a sonorant or $s$, it is doubtful that that gap is statistically significant. Rather the rarity of such words appears to be due to the relatively low productivity of those suffixes (in comparison to -less or -ness) 93 and the low ratio of potential bases with the required phonological properties. For example, there are several hundred trochaic nouns in English which end in a sonorant compared to only about a dozen which end in a $p$. The existence of twenty -ful-suffixations based on trochaic stems ending in a sonorant compared to only one ending in - $p$ (i.e. wórshipful) is therefore to be expected. The rarity of dactylic stems presumably reflects the rarity of non-Germanic bases in -ful, -dom, or -some suffixation. ${ }^{94}$ Note finally that while capturing rather dubious gaps in -ful, -dom, or -some suffixation, Burzio's analysis fails to account for the stress-related gaps in -ize, -eer, or -ous suffixation.

\section{PHONOLOGICAL CONSTRAINTS ON MORPHOLOGICAL ANALYSIS}

In sections 2 and 3 I have argued for a limitation to native word formation when describing the conditions on the synthesis of words. In this section I will present evidence which suggests that the analysis of words, specifically base recognition, is subject to independent phonological conditions (cf. Raffelsiefen 1993, 1998). Those conditions are similar to identity constraints on word formation in that they require certain aspects of the phonemic representations of derived words and their base to be identical. 95

There is evidence that English hearers relate irregular plural forms as shown in (1a) to the cognate singular forms only if the pairs exhibit no more than one alternation. 96 Compare the cognates in (101a), which exhibit a single voicing alternation and for which recognition succeeds, with the cognates in (101b), which exhibit an additional vowel alternation and for which recognition fails. The shafted arrow indicates morphological analysis (i.e. ' $\mathrm{A} \rightarrow \mathrm{B}$ ' means ' $\mathrm{B}$ is recognized as the base of $\mathrm{A}^{\prime}, \mathrm{A}^{*} \rightarrow \mathrm{B}^{\text {' means }}$ 'B is not recognized as the base of $\mathrm{A}^{\prime}$ ).

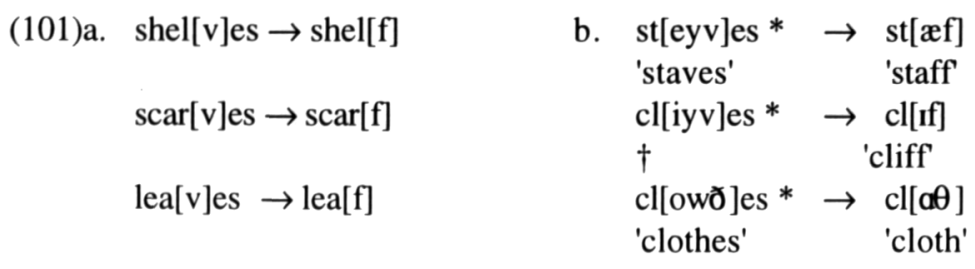


Failed base recognition in the pairs in (101b) is manifest in semantic differentiation and the development of back-formed singulars (e.g. stave), the development of pluralia tantum (e.g. clothes), the archaization of words (e.g. cleeves), and the development of innovative plural forms (e.g. staffs, cliffs, cloths).

Assuming that the destabilization of the pairs in (101b) is due to a lack of phonologocal identity the question arises of why those pairs, but not the pairs in (101a), contain two alternations. All voicing alternations in (101) are due to either fricative devoicing in coda position or fricative voicing in medial onset position which applied at a time when the plurals were still disyllabic. At that time, the plurals were also susceptible to vowel lengthening in open syllables. That rule caused no change in the plurals in (101a) because their vowel was either already long (e.g. leaves, houses, thieves), or the first syllable was closed (e.g. shelves, scarves, wolves). By contrast, vowel lengthening affected the plurals staves and cleeves, which originally had a short vowel in open syllable. As a result the vowels in the pairs staves-staff and cleeves-cliff were no longer identical. In the pair clothes-cloth, the vowel alternation is due to a rule which shortened back mid vowels before the interdental fricative (cf. broth, sloth, etc). It is because of these purely phonological differences that the pairs in (101b), but not in (101a), developed multiple alternations and destabilized.

The data in (102) support the claim that the plurals in (101b) are no longer related to the cognate singular forms because of the number of alternations, and not because of the type (i.e. vowel alternations). The examples in (102b) are given in $\mathrm{OE}$ orthography, where $\left\langle c^{\prime}\right\rangle$ represents the palatal voiceless affricate. All pairs in (102b), but none of the pairs in (102a), show signs of destabilization.

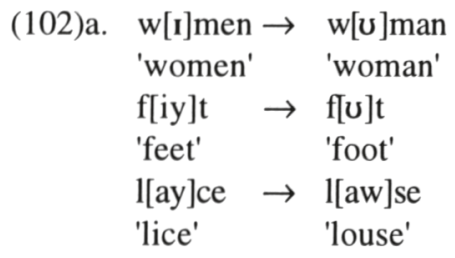

$\begin{array}{lll}\text { b. } & \text { ae:c' } * \rightarrow & \text { a:c } \\ \dagger & \text { 'oak' } \\ \text { bre:c' } * & \rightarrow & \text { bro:c } \\ \text { 'breeches' } & \dagger \\ \text { be:c' } * & \rightarrow & \text { bo:c } \\ \dagger & & \text { 'book' }\end{array}$

The crucial difference between the pairs in (102a) and (102b), all of which exhibit vowel alternations, concerns the place of articulation of the postvocalic consonant. The singular forms in (102b) have a back vowel followed by a velar stop, which, due to umlaut, was subject to palatalization in the corresponding plural forms. The result was that the pairs developed two alternations and destabilized. This phonological account of destabilization also explains a gap in the stable umlaut pairs in (102a): there are no pairs involving postvocalic velars.

The data in (102a) show that plural-singular pairs in English can remain stable in spite of developing a rare or isolated alternation (cf.w[I]men-w[U]man, g[iy]se$g$ [uw]se) whereas such pairs necessarily destabilize when developing multiple alternations. This generalization cannot be expressed in a model of morphological 
synthesis but shows that morphological analysis is determined by specific identity conditions. The conditions are that the relatedness between plurals and singulars in English can succeed only if either all consonants or the initial minimal word, which includes the onset and at least two moras, are identical. These conditions pertain specifically to plural-singular relations in English. Tense relations can be recognized even if they involve more than one alternation (e.g. left-leave, taught-teach), ${ }^{97}$ whereas in derivational morphology, base recognition can be thwarted by even a single alternation. Compare the causatives in (103a), which are clearly related to their base verbs, to the causatives in (103b), which exhibit a voicing alternation and are no longer related to their historical base:

$$
\begin{aligned}
& \text { (103)a. } \quad \text { warm] }_{\mathrm{TV}} \rightarrow \text { warm] }_{\mathrm{A}} \\
& \mathrm{cooll}_{\mathrm{TV}} \rightarrow \mathrm{cooll}_{\mathrm{A}} \\
& \text { clean }]_{\mathrm{TV}} \rightarrow \text { clean }_{\mathrm{A}}
\end{aligned}
$$
b. $\left.\quad \operatorname{clo}[\mathrm{z}] \mathrm{e}]_{\mathrm{TV}} * \rightarrow \operatorname{clo}[\mathrm{s}] \mathrm{e}\right]_{\mathrm{A}}$ 'close' 'close'$$
\left.\mathrm{sa}[\mathrm{v}] \mathrm{e}]_{\mathrm{TV}} * \rightarrow \mathrm{sa}[\mathrm{f}] \mathrm{e}\right]_{\mathrm{A}}
$$$$
\text { 'save' 'safe' }
$$$$
\left.\operatorname{lo}[\mathrm{z}] \mathrm{e}]_{\mathrm{TV}} * \rightarrow \operatorname{lo}[\mathrm{s}] \mathrm{e}\right]_{\mathrm{A}}
$$$$
\text { 'lose' 'loose' }
$$

The claim that base recognition succeeds in (103a) is supported by the fact that the causatives can be paraphrased with reference to their etymological base (cf. (104a)). This is not the case for the causatives in (103b):
(104) a. to warm the meal
'to make the meal warm'
to cool the beer
'to make the beer cool'
to clean the pipe
'to make the pipe clean'
b. to close the door
*'to make the door close $]_{\mathrm{A}}$ '
to save time
*'to make the time safe'
to lose money
*'to make the money loose'

Base recognition in derivationally related words which exhibit voice alternations does not necessarily fail as is shown by the pairs in (105):

$$
\begin{aligned}
& \text { excú[s } \left.]_{N} \rightarrow \text { excú[z] }\right]_{V} \\
& \text { abú[s] }]_{N} \rightarrow \text { abú[z] }
\end{aligned}
$$

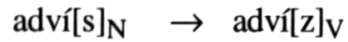

$$
\begin{aligned}
& \text { belíe[f } \left.]_{N} \rightarrow \text { belíe[v }\right]_{V} \\
& \text { relíe }[\mathrm{f}]_{\mathrm{N}} \rightarrow \text { relíe[v] }
\end{aligned}
$$

The claim that the nouns in (105) are related to their etymological base is supported not only by their meaning affinities but also by the evidence from noun to verb conversion. Generally, English nouns can be converted to verbs (cf. (106a)) unless they are relatable to a base (cf. (106b)):98
(106) a. to culture (*cult)
b. $\quad *$ to failure $(\rightarrow$ fail $)$ 


$$
\begin{array}{lll}
\text { to pity } & (* \text { pit }) & * \text { to safety }(\rightarrow \text { safe }) \\
\text { to mirror } & (* \text { mirr }) & * \text { to error } \quad(\rightarrow \text { err })
\end{array}
$$

The fact that the nouns in (105) resist conversion to verbs is accordingly indicative of successful base recognition (cf.*to excú[s], *to abú[s], *to adví[s], * to belíe[f], *to relie [f]). While there is clear evidence then that the nouns in (105) are analysed as deverbal in spite of the voice alternation it is less clear what role that alternation itself plays in the analysis. Significantly, base recognition appears to succeed also for the cognates in (107a), which exhibit isolated alternations, as is indicated by both the semantic and morphological properties of the nouns (i.e. resistance to verb conversion as shown in (107b)):

$$
\begin{array}{ll}
\text { (107)a. } & \text { intén }[\mathrm{t}]_{\mathrm{N}} \rightarrow \text { intén }[\mathrm{d}]_{\mathrm{V}} \\
& \text { offén }[\mathrm{s}]_{\mathrm{N}} \rightarrow \text { offén }[\mathrm{d}]_{\mathrm{V}} \\
& \text { respón }[\mathrm{s}]_{\mathrm{N}} \rightarrow \text { respón }[\mathrm{d}]_{\mathrm{V}} \\
& \text { appláu[z} \left.]_{\mathrm{N}} \rightarrow \text { appláu[d] }\right]_{\mathrm{V}} \\
& \text { decéi }[\mathrm{t}]_{\mathrm{N}} \rightarrow \text { decéi }[\mathrm{v}]_{\mathrm{V}}
\end{array}
$$
b. * to intén[t]
*to offén[s]
*to respón[s]
*to applau[z]
*to decei[t]

In view of the non-recurrence of the alternations in (107a) it appears that the conditions for base recognition must refer to the identity of phonological structure. Specifically, the data show that base recognition for iambic nouns succeeds if the cognates exhibit identical initial minimal words. ${ }^{99}$ It is unclear why this condition is insufficient for the analysis of the causatives in (103b). Perhaps the phonological conditions for base recognition differ for abstract nouns and causative verbs. Also the difference in the number of syllables between the verbs in (103b) and the nouns in (105) could play a role. It is further conceivable that the markedness of iambic nouns in English alerts the hearer to the likely existence of a base. 100 What seems clear is that one and the same alternation can impede the analysis of some words but not others depending on the specific conditions for base recognition.

To summarize, the data reviewed here suggest that the phonological conditions for base recognition are identity requirements which can be relaxed because of specific properties of the input word (e.g. inflectedness, markedness in phonological form). For words which lack those properties alternations will result in failed base recognition, regardless of how frequent the alternation is (cf. voice alternations in English fricatives in (101b) and (103b)). For words which have those properties base recognition can succeed regardless of how isolated the alternations are. (e.g. the pairs in (102a) and (107a)). None of those generalizations can be expressed in a synthesis model of morphology.

\section{CONCLUSIONS AND OUTLOOK}

The methodological basis of this description of English morphophonology is the 
limitation to native word formation. This limitation is motivated by the observation that there are separate conditions for morphological synthesis and analysis.

I have presented evidence that in English only glide- and vowel-initial suffixation exhibits phonologically conditioned gaps and allomorphy. I have argued that both types of effects are related in that they serve to satisfy constraints on output forms. The observation that phonologial effects in word formation depend on the initial segment of the suffix is explained by ranking constraints to the effect that onsetless syllables (or syllables with insufficient onsets) are integrated into the pword of the stem. The generalization is then that English suffixes exhibit phonological effects only if they are fused into one pword with their stem. This generalization suggests that in English, the pword constitutes the domain for phonological constraints in word formation, which is not true universally (cf. the German data discussed at the end of section 6). 101

While the phonological effects exhibited by English suffixation can be described with reference to a relatively small number of independently motivated constraints there is clear evidence that there are no suffixes, not even homophonous suffixes, which show the same phonological effects. Unless one is willing to sweep those systematic differences under the rug (cf. the indiscrimate assignment of those suffixes to one or two levels in Lexical Phonology) it must be concluded that the constraint ordering differs for each suffix. The acquistion of English morphophonology amounts thus to acquiring a particular ordering of (innate) constraints for each affix. 102

The phonological constraints on word formation apply at the phonemic level and can be divided into three groups: phonological constraints (PHON), identity constraints (IDENT), and M-PARSE. For each of the three types of phonological effects in word formation (see figure (9)) a constraint from one group is dominated by constraints from the other two groups, as is shown in table 108. Phonologically conditioned gaps are largely confined to derivational morphology which suggests that for inflectional suffixes the constraint M-PARSE is generally undominated. 103

(108) a. non-canonical sound patterns

b. allomorphy

IDENT, M-PARSE $>>$ PHON

c. gaps

PHON, M-PARSE $>>$ IDENT

IDENT, PHON $\gg$ M-PARSE

The observation that there exist phonological effects in word formation which are clearly output-oriented raises the question of whether reference to output forms suffices to describe all such effects. The answer to this question depends to some extent on the linguist's bias. Consider for example the suffix -ous, which prefers trochaic stems (cf. section 8). For those who believe that all feet should be binary that restriction can only be expressed with reference to input forms. However, if one feels free to make use of the complete foot inventory established within traditional metrics, that restriction can be expressed as a requirement to yield dactylic feet in output forms. Recall that reference to dactyls in output forms is needed independently to capture the distribution of -ery/-ry or -encel-ency (cf. section 5). ${ }^{104}$ Similarly, the fact that the nominal suffix -al attaches only to iambic feet is expressable in terms of 
output forms, but only if one is willing to refer to amphibrachs.

Consider next a case of a seemingly arbitrary segmental restriction. The English glide-intial suffixes -ion and -ure attach only to stems ending in a coronal obstruent. Significantly only these obstruents allow the resulting formations to have less sonorous and therefore improved onsets, i.e. the obstruents $\check{s}, \check{z}, \check{c}$ and $\check{j}$. That is, stem-final coronals are the only consonants which assimilate with palatal glides such that structure preservation, the constraint which prohibits complex onsets, and certain identity constraints are satisfied. The identity constraints in question require the features [+obstruent], [+coronal] and [+palatal] of the output to correspond to identical features in the input. 105

Limiting reference to output constraints is desirable because it allows for a highly restrictive theory. A few predictions which would follow from such a theory are listed in (109) and (110):

\begin{tabular}{|l|l|l|}
\hline & Possible gaps & Relevant constraints \\
\hline a. & $\begin{array}{l}\text { Suffixes which include a liquid } \mathrm{L}_{\mathrm{i}} \text { can } \\
\text { resist attachment to a stem which } \\
\text { contains } \mathrm{L}_{\mathrm{i}}, \text { but they cannot select such a } \\
\text { stem. }\end{array}$ & $\begin{array}{l}\text { There is a constraint } * \mathrm{~L}_{\mathrm{i}} \mathrm{L}_{\mathrm{i}} \text {, but there is } \\
\text { no constraint which re-quires that words } \\
\text { contain identical liquids. }\end{array}$ \\
\hline b. & $\begin{array}{l}\text { Suffixes which consist of a sequence } \\
\text { V } \mathrm{C}_{\mathrm{i}} \text { can resist attachment to a stem } \\
\text { ending in } \mathrm{C}_{\mathrm{i}}, \text { but they cannot select such } \\
\text { a stem. }\end{array}$ & $\begin{array}{l}\text { There is a constraint SHELL, but there is } \\
\text { no constraint which requires that a syl- } \\
\text { lable nucleus be flanked by identical } \\
\text { consonants (cf. Vennemann 1988). }\end{array}$ \\
\hline c & $\begin{array}{l}\text { Vowel-initial suffixes can resist attach- } \\
\text { ment to a stem which ends in a conso- } \\
\text { nant with high sonority but they cannot } \\
\text { select such a stem. } 106\end{array}$ & $\begin{array}{l}\text { Syllable onsets are the more preferred } \\
\text { the less sonorous they are (cf. } \\
\text { Vennemann 1988). }\end{array}$ \\
\hline d & $\begin{array}{l}\text { Suffixes with initial stress can resist at- } \\
\text { tachment to a stem which ends in a } \\
\text { stressed syllable but they cannot select } \\
\text { such a stem. }\end{array}$ & $\begin{array}{l}\text { There is a constraint *CLASH, but there is } \\
\text { no constraint which requires adjacent } \\
\text { syllables to be stressed. }\end{array}$ \\
\hline
\end{tabular}


(110)

\begin{tabular}{|l|l|l|}
\hline & Possible allomorphy rules & \\
\hline a. & $\begin{array}{l}\text { Identity violations may only result in the } \\
\text { dissimilation but not in the assimilation of } \\
\text { (non-adjacent) liquids. }\end{array}$ & see (109a) \\
\hline b. & $\begin{array}{l}\text { Identity violations may only result in the } \\
\text { dissimilation but not in the assimilation of } \\
\text { consonants which flank the nucleus }\end{array}$ & see (109b) \\
\hline c & $\begin{array}{l}\text { Identity violations may only result in a } \\
\text { sonority decrease of a consonant in } \\
\text { onset position. }\end{array}$ & see (109c) \\
\hline d & $\begin{array}{l}\text { Identity violations may only result in } \\
\text { alternating stress but not in a stress clash. }\end{array}$ & see (109d) \\
\hline
\end{tabular}

By contrast, a theory which also allows for constraints on input forms in terms of phonological subcategorization frames entails none of the predictions above.

The question of whether those predictions hold universally and of whether all phonological effects in word formation can be expressed in terms of output constraints is of course an empirical issue in need of further investigation. ${ }^{107}$ Clearly, the restriction to output constraints is theoretically interesting only insofar as those constraints are independently motivated and can be assumed to be universal. 108 To ensure independent motivation I propose to admit only those constraints which play a role in sound change. 109 This condition holds for all constraints discussed in this paper. Note finally that a strictly output-oriented description requires the abandonment of the widely accepted limitation to binary feet. Hopefully this conclusion will encourage the proponents of foot binarity to reexamine the empirical basis for their assumption.

\section{NOTES}

1 In this paper I develop several ideas presented in Raffelsiefen (1992), (1993), (1996). Some of the new proposals discussed here were first presented at the Annual Meeting of the Deutsche Gesellschaft Für Sprachwissenschaft in Düsseldorf in March 1997. I thank Geert Booij, George Smith, and two anonymous reviewers for helpful criticisms. Special thanks are due to Mike Brame for many hours of discussion and to Bruce Straub for proof-reading.

2 They do not necessarily appear exclusively in onset position because of ambisyllabicity. Specifically, consonants which are preceded by a [-consonantal] segment and followed by an unstressed vowel are ambisyllabic in American English, which is true regardless of the morphological structure of the word (cf. the examples $b u[\mathrm{r}]$ er 'butter', wri[r]er 
'writer', where the flap indicates ambisyllabicity) (cf. Kahn 1976).

3 According to Kahn voiceless stops are always aspirated in syllable-initial position even if the following syllable is unstressed (cf. Kahn 1976: $41 \mathrm{ff}$ ).

4 The stops $/ \mathrm{p} /$ and $/ \mathrm{t} /$ are unreleased in syllable final position if no obstruent precedes (cf. Kahn 1976: 48).

5 For some speakers the LOI (i.e. 'Law of Initials') is dominated by a phonological constraint which prohibits complex onsets in stressless syllables. Those speakers have different syllabifications for vowel- versus consonant-initial suffixes only in the pair triple+oid -trip+like, but not in the remaining pairs, which involve stressless suf-fixes.

6 The Law of Initials requires all prevocalic consonants to be syllabified as syllable onsets unless the clusters in question do not occur word-initially. Since the cluster $p l$ does occur word-initially (cf. plain, plum) this cluster should be syllabified in onset position if a vowel follows.

7 To my knowledge the assumption that only vowel-initial or glide-initial suffixes are integrated into the pword of the stem is consistent with English syllable structure. Contradicting evidence is cited by Halle and Mohanan (1985), who posit a rule of $l$-resyllabification in compounds to account for their observation that the $l$ constitutes the onset of the following syllable in the compound seal office, but not in the phrase the seal offered a doughnut. This rule does not appear to be part of standard British or American English. It is odd for a rule of resyllabification to be confined to one segment.

8 It is unclear if this suffix, which was originally an independent word, still constitutes a separate pword or should be represented as a clitic. Clearly, the suffix constitutes a foot. For more discussion of the prosodic structure of suffixed words see section 6 .

9 Another term for identity constraint is 'output-output correspondence constraint'. Identity constraints hold only between independent words in English and are thus closely related to the notion of the cycle developed in Brame (1974).

10 The suffix - acy, for instance, requires the stress but not the wordfinal VC-string of the base to be preserved as is shown by the example in (7).

11 Perhaps identity effects w.r.t. syllable structure do not exist. In that case there should be no languages in which stem-final consonants followed by a vowel-initial suffix occur in coda position to satisfy identity w.r.t. the base. To resolve this issue it is necessary to establish criteria for distinguishing suffixation from compounding. Words like English wide-eyed, cross-eyed, clear-eyed, bug-eyed but also German orkanartig 'like a hurricane', aalartig 'like an eel', wolkenartig 'like clouds' are clearly compounds although for semantic reasons English -eyed or German -artig do not occur by themselves.

12 For universal constraints on syllable structure, see Vennemann (1988). The conditions on syllabification in American English are described by Kahn (1976).

13 Some of the data discussed here and their description in terms of affix-specific constraint rankings have also been presented in Raffelsiefen (1996).

14 Cf. Liberman and Prince (1977).

15 The quality of the first vowel is based on the spelling of the word (for a discussion of this point see section 7).

16 To eliminate candidates like giràffenéer, which also satisfy both *CLASH and IDENT(S), M-PARSE must be dominated by an additional identity constraint which prohibits epenthesis.

17 Relative prominence in the winner in (20) is determined by an independent phonological constraint which requires that tense high vowels in word-final syllables carry main 
stress.

18 The OED lists roughly 1400 -ize-formations. The fact that among these entries there are perhaps twenty verbs which are based on words with final stress (including monosyllabic words) still leaves a statistically significant gap to be explained. These exceptions are usually characterized by low token frequency and are typically rejected by native speakers (e.g. ?concretize, ?Marxize). Considering the fact that English is commonly used by non-native speakers the occurrence of such miscoinages is remarkably low. 19 Similarly it is conceivable that -ize suffixation like áptize should be considered ungrammatical even if all other suffixes were to freely violate the constraint ${ }^{*} \mathrm{CLASH}$ (cf. the suffix $-e e$ ).

20 The ungrammaticality of the nouns in (23b) cannot generally be explained by blocking since several verbs lack derived nominals (e.g. ignore, remain, secure, deserve), whereas others coexist with potential blockers (e.g. adaptation, adaption; perturbation, perturbance, perturbancy; accusation, accusal).

21 The only unclear case is the noun indentation which, however, has a corresponding form in French (i.e. French indentation).

22 Cf. the notion of correlative patterns discussed in section 7.

23 Following Chomsky and Halle (1968), Pater (1995) analyses the pretonic stress in words like còndènsátion as an identity effect with respect to the verb condénse. Granted that no nouns in -ation are actually derived from iambic verbs in English the existence of such systematic identity effects seems unlikely. In fact, the stress patterns of the nouns in question are predictable on the basis of their segmental structure, specifically on the basis of the sonority of the segment which closes the pretonic syllable. That is, stress is most stable if that syllable is closed by an obstruent (cf. àdàptátion, èxpèctátion, tìcktàcktóe), somewhat stable if it closed by a nasal (cf. còndèmnátion còndemnátion, còndènsátion còndensátion), least stable if it closed by $/ \mathrm{r} /$ (cf. informátion, pèrturbátion), and impossible if the syllable is open (cf. èxplanátion, dèrivátion). Vowel height plays a role as well as stress is most stable for low vowels (dèmàrkátion, chimpànzée).

While identity effects can generally not be established for any of the -ation nouns which happen to have iambic cognates in English the ungrammaticality of medial stress in words like còmpensátion cannot be explained on purely phonological grounds. This noun, however, is based on a verb ending in -ate (i.e. cómpensàte) which means that it can be formed natively. (The relevant rule of word formation involves the correlative pattern Xate-Xation discussed in section 7.) The ungrammatical medial stress in *còmpènsátion can accordingly be described by a constraint which requires stress identity w.r.t. its base cómpensàte. (This is not to deny that sporadically loanwords can be affected by identity effects as a result of successful base recognition (cf. section 9). For example, the vowel change in $o b[\varepsilon]$ sity to $o b[i y]$ sity is certainly an identity effect in relation to the adjective obese.)

24 The assumption that affixes can become productive only if there is a large set of potential bases which satisfy their specific syntactic and phonological constraints accounts also for the low productivity of the suffix -ify in comparison to -ize. That is because the suffix -ify starts with a stressless syllable and attaches to nouns or adjectives, which typically end in a stressless syllable. As a result -ify suffixation would typically violate either the constraint IDENT(S) (e.g. * randómifỳ-rándom) or the constraint *LAPSE, which prohibits adajcent unstressed syllables (e.g. rándomify). It appears then that the potential productivity of suffixes is confined by their sound shape and the canonical sound 
patterns of the syntactic category they subcategorize for.

In addition, the non-coronal consonant in the suffix -ify conceivably also contributes to its low productivity. In consonant-initial suffixes, which are insensitive to the phonological properties of the stem, non-coronal segments seem to generally impede productivity (cf. the low productivity of the nominal suffixes -dom, -ship, compared to their rival -ness)

25 The examples in (28a) are American English. In British English all nonlateral liquids in coda position have disappeared. The fact that liquids in onset position have never disappeared indicates that the constraint ONSET has consistently dominated the constraint ${ }^{*} \mathrm{~L}_{\mathrm{i}} \mathrm{L}_{\mathrm{i}}$ in all varieties of English.

26 Consider also the sound changes in the Romance languages shown in (i), all of which 'conspire' to satisfy the constraint ${ }^{*} \mathrm{~L}_{\mathrm{i}} \mathrm{L}_{\mathrm{i}}$ :

(i) Latin: arbor 'tree' > Spanish: arbol 'tree' / Italian: albero 'tree'

Latin: marmor 'marble' > Spanish: marmol 'marble' / Italian: marmo 'marble'

27 Verbs which exhibit $* \mathrm{~L}_{\mathrm{i}} \mathrm{L}_{\mathrm{i}}$ violations are typically based on nonverbs (cf. (ia)) or are onomatopoetic (cf. (ib)):
(i)a.
label $\left(\right.$ label $_{\mathrm{N}} \rightarrow$ label $\left._{\mathrm{V}}\right)$
level $\left(\right.$ level $_{\mathrm{N}} \rightarrow$ level $\left._{\mathrm{V}}\right)$
belittle (be+little $\rightarrow$ belittle $_{\mathrm{V}}$ )
b. lull
roar
murmur

28 Following common practice the term 'onset' will be used as an alternative expression for 'head' and refer to all segments which precede the nucleus within a syllable. Vennemann (1988) restricts the term 'onset' to the first segment within the head.

29 The observation that $* \mathrm{~L}_{\mathrm{i}} \mathrm{L}_{\mathrm{i}}$-violations are worst when they occur within a syllable accounts for the fact that the allomorph -ar never appears when the base ends in an $r$ (cf. culture+al $\rightarrow$ cultural $(*$ culturar $)$ )

30 Suffix-allomorphy is especially common when the output consists of a trochee with identical syllable onsets (e.g. bulb+al $\rightarrow$ bulbar, valve+al $\rightarrow$ valvar, etc).

31 Apparent counterexamples like nuclear are loanwords (cf. French nucléaire).

32 The fact that $l$ was replaced not by $r$ but by $n$ in the English dialect words sinable and nittle indicates a higher-ranked preference for syllable onsets with low sonority (cf. Vennemann 1988).

33 The constraint SHELL is discussed in Vennemann (1988), who notes that SHELL -violations are worse if the syllable shell includes additional speech sounds. The constraint SHELL differs accordingly from the other syllable-based dissimilatory constraints in that it does not refer to identical syllable nodes.

34 For the suffix -ous SHELL-violations are sporadically avoided at the expense of other constraint violations. For example, the native coinage gaseous, which is based on gas, is pronounced either [gæšəs], thereby violating IDENT(C), or [gæsiəs], thereby violating the constraint which prohibits epenthesis.

35 The productivity of these suffixes is typically subject to semantic restrictions as well. The suffix -eer, for example, attaches most productively to nouns denoting weapons. 36 This generalization might be incorrect as those -ify-suffixations could also be derived without violating IDENT(S) from the nouns humidity, rigídity, fluidity by truncation. This 
is clearly a possibility since for each - ify-suffixation the corresponding noun in -ity is attested earlier.

37 The fact that constraint satisfaction is achieved by truncation is remarkable since truncation implies a stronger violation of identity constraints than seems necessary. That is, the $\mathrm{ONS}_{\mathrm{i}} \mathrm{ONS}_{\mathrm{i}}$-violation in ${ }^{*}$ maximumize could also have been avoided by modifying just a single feature (cf. maximunize, maximubize, etc.). Interestingly, truncation in English always affects a word-final $\mathrm{VC}_{\mathrm{o}}$ string (e.g. -um, -on, -in, -is, -ate).

38 The noun evacuee, which is related the verb evacuate, is not a counterexample to this claim since it is borrowed from French évacué: In English word formation, truncation does not apply in comparable verbs (cf. evaluate $+e e \rightarrow{ }^{*}$ evaluee, situate $+e e \rightarrow *$ situee). Cf. also truncation in -ese $e_{1}$-suffixations as in Lebanon+ese $\rightarrow$ Lebanese versus Pentagon+ese $\rightarrow$ Pentagonese, Aragon+ese $\rightarrow$ Aragonese .

$39 E_{s e} e_{1}$-suffixation differs from -ee or -ize suffixation in that $\mathrm{ONS}_{\mathrm{i}} \mathrm{ONS}_{\mathrm{i}}$-violations are generally preferred to gaps (cf. Húnán+ése $\rightarrow$ Hùnanése).

40 Recall that M-PARSE dominates * $\mathrm{CLASH}$ for the suffix -ee (cf. kissée, pàyée, thròwée, etc.)

41 Marchand's claim that in the last two hundred years the suffix has only attached to stems ending in $-t$ or $-d$ is not correct (cf. Marchand 1969). Counter-examples listed in the OED include the formations blithen, closen, coarsen, crispen, densen, grossen, largen, pinken, richen, steepen. Perhaps it is significant, though, that none of these formations has gained currency.

42 The OED lists three counter-examples to the gap in (53c): dullen, palen, dimmen. However, each of these verbs is described as 'rare' and is documented with only one citation.

43 The implicational relations considered here are also the subject of Prince and Smolensky's formal analysis of sonority preferences within syllables (cf. Prince and Smolensky 1993: 140f). Unfortunately those authors fail to distinguish syllable onsets and syllable codas when discussing those preferences, but just refer to syllable margins.

44 Vennemann's precise formulation is that a syllable head is the more preferred the greater the Consonantal Strength of its onset and that a syllable coda is the more preferred the less the Consonantal Strength of its offset, where the term 'onset' refers to the first speech sound in the syllable head and the term 'offset' refers to the last speech sound in the syllable coda (cf. Vennemann 1988: 13, 21). These preferences are manifested both in structure-preserving historical changes such as the spirantization of the glide $[w]$ in German (cf. [w] all > [v] all) and in allophonic processes such as the aspiration of voiceless stops in onset position in English compared to their unreleasedness in offset position (cf. Vennemann (1988: 13ff)).

45 Verbs like soften, hasten, fasten, etc. may suggest that the constraint IDENT needs to be modified to the effect that only the first post-vocalic consonant in the base must be preserved. However, new coinages like swif[t]en argue against such a modification. Alternations in cognates like soften-soft are best analysed as the result of the historical rule of $t$-loss between a fricative and a syllabic sonorant (cf. of $[\mathrm{t}]$ en $>$ of $[\varnothing]$ en, cas $[\mathrm{t}] l e>$ cas[Ø]le), which is irrelevant for describing constraints on -en-suffixation.

46 The initial syllable in each noun in (59a) is bimoraic while the initial syllable in each noun in $(59 \mathrm{~b})$ is monomoraic. This account presupposes that the velar glide in $G[o w] a$ is syllabified in onset position and hence does not contribute to syllable weight. For the suffix - ese $_{2}$, hiatus is avoided by avoiding suffixation altogether. 
47 Burzio's description of English stress differs from other descriptions in that he rejects the notion of stress-neutrality, which also applies to consonant-initial suffixes. The relevant data are discussed in section 8.2.

48 Clearly, vowel 'insertion' in (64) could not be motivated on metrical grounds since the vowel appears regardless of the stress contour of the base. For illustration consider native -(i)cide derivations such as hérbicide (cf. herb), parénticide (cf. párent), insécticide (cf. ínsèct), èlefánticide (cf. élephant), pàrasíticìde (cf. párasite).

49 Citing the example beautiful Halle and Mohanan (1985: 67) claim that the rule of stem-final tensing does not apply before the suffix -ful, giving rise to the alternation beaut $[\mathrm{i}]$-beaut[ə]ful. However, according to both Jones and Gimson (1977) and Kenyon and Knott (1944) the alternation in question is not typical for the suffix -ful (cf. the pairs transcribed with identical vowels like fanc[1]-fanc[1]ful, $\operatorname{merc}[\mathbf{I}]-\operatorname{merc}[\mathbf{I}]$ ful, plent $[\mathbf{1}]-$ plent [1]ful, dut[I]-dut[I]ful). The fact that beautiful is the only-ful-suffixation which is transcribed with a stem-final schwa in both dictionaries is certainly due to the high frequency of the adjective beautiful compared to those other -ful derivations.

50 There is some evidence that the consonant-initial suffixes originally constituted separate pwords (cf. section 6). It is not always clear if the fusions in (66a) result from the loss of internal pword boundaries as is illustrated in (66b), or if they occurred after the decay of the pwords which historically dominated the suffixes and hence involve the prosodic integration of a clitic as is presumed in (66a).

51 As is shown by these examples the question of which palatal fricative or affricate is yielded by suffixation is subject to variation. The suffix -ion, which is almost never used in native word formation, shows the same phonological effects (e.g. òbsoléte+ion $\rightarrow$ (òbsolétion) $)_{\omega}$ ).

52 Sequences consisting of an alveolar obstruent and a palatal glide necessarily involve pword boundaries (cf. brigh[t][y]ellow, cour[t][y]ard).

53 The words heavenward and netherward are exceptions to this generalization.

54 There is an alternative explanation for $w$-loss in cases where the schwa historically corresponds to a round vowel. That is, $w$ may have disappeared before the vowel reduced to schwa due to a constraint against clusters consisting of round glides and round vowels (e.g. [sw]ord $>$ [s]ord, [tw] $o>[\mathrm{t}] o$ ).

55 Since its historical base became obsolete (i.e. †awke) the adjective awkward is generally perceived as a simplex. Unfortunately there are very few simplexes which allow one to study the strictly phonological constraints on the syllabification of the relevant clusters in unstressed syllables.

56 The fact that the suffix ry/-ery never attaches to words ending in $-r$ indicates that the constraint against identical syllable nodes in adjacent syllables dominates M-PARSE. The suffix also fails to attach to words ending in $-y$, which indicates a constraint against identical syllable nuclei in adjacent syllables (e.g. *arryry, ${ }^{*}$ pityry, *envyry).

57 The preference for dactyls also accounts for the fact that words like affluency, cómpetency, pértinency, cónsequency, etc. have become obsolete in English whereas words like décency, úrgency, etc. persist.

58 Wiese claims that the complex words in (73) are based on participles. However, neither the suffix -ness nor the suffix -ly attach to participles as is shown by the unacceptability of words like *boughtness, *talkedness, *bakedly, *eatenly, etc. The claim that the suffixes -ness and -ly are based on adjectives in (73) is supported by the facts that the respective bases can appear in prenominal position (e.g. the distressed teacher vs. 
* the bought car) and that they are gradable (very distressed, quite distressed vs. *very bought, *quite bought).

59 The alternations in (73) have come into existence because schwa loss in trochees was not phonologically conditioned but rather involved a series of analogical changes. Those changes were initiated by the (phonologically conditioned) schwa loss in dactyls (cf. Luick 1964: 508ff), which led to alternations in the form of the participle suffix (e.g. detérmin $+[\emptyset] \mathrm{d}$ versus confús $+[0] \mathrm{d})$. The observation that schwa subsequently disappeared in that suffix (unless its loss would have resulted in a cluster of homorganic stops (guard[ə]d ${ }^{*}>$ guard[Ø]d), but not in phonologically similar endings (e.g. wick[ə]d, nak[ə]d, wretch[ə]d, dogg[ə]d), indicates the analogical conditioning of schwa loss in trochaic participles. This conditioning did not apply in adjectives, which were historically derived from participles, which led to the alternations in (i).

(i) a. diffus $[\varnothing] \mathrm{d}_{\text {PART }}-\operatorname{diffus}[ə] \mathrm{d}_{\mathrm{A}}\left(>\operatorname{diffus}[\varnothing] \mathrm{d}_{\mathrm{A}}\right)$ $\operatorname{prepar}[\varnothing] \mathrm{d}_{\text {PART }}-\operatorname{prepar}[\ni] \mathrm{d}_{\mathrm{A}}\left(>\operatorname{prepar}[\varnothing] \mathrm{d}_{\mathrm{A}}\right.$ distress $[\varnothing] d_{\text {PART }}-\operatorname{distress}[\ni] \mathrm{d}_{\mathrm{A}}\left(>\operatorname{distress}[\varnothing] \mathrm{d}_{\mathrm{A}}\right)$

b. $\left.\operatorname{suppos}[\varnothing] \mathrm{d}]_{\mathrm{PART}}-\operatorname{suppos}[\ni] \mathrm{d}\right]_{\mathrm{A}}$ alleg[Ø]d $]_{\text {PART }}$ - alleg[ə]d $]_{\text {A }}$ learn[Ø]d $]_{\text {PART }}$ - learn[ə]d] $]_{A}$

The data in (ia) illustrate the subsequent loss of the schwa in the adjectives which is due to analogical leveling w.r.t. the schwaless participles or perhaps to innovative conversions based on such participles. (Adjectival forms like diffus[ə]d, prepar[ə]d, distress[ə]d are marked as 'poetic' in the OED). Adjectives in which the schwa has remained are typically lexicalized as is illustrated in (ib). The alternations shown in (73) indicate that the leveling illustrated in (ia) did not simultaneously affect all derivations based on the adjectives.

60 Some speakers still prefer the fossilized forms with schwa. The judgements are generally not very clear since none of these words are used in colloquial English.

61 The native speakers I have consulted have expressed an intuition that the suffix in those expressions is -edness. Conceivably, such a fused suffix has developed by reanalysis for those speakers (cf. the German suffix -igkeit) and can be used to coin new words. The only attested case is the noun well-formedness (and, by analogy, ill-formedness), which like markedness is also linguistics jargon according to the OED. The suffix -edness is clearly not part of ordinary English. There is no evidence for a reanalysed fused suffix -edly.

62 In a detailed study Bauer (1992) concludes that -ly-suffixation to adjectives ending in $-l y$ is of limited productivity. He also argues that in these cases productivity is affected more strongly by the morphological than the phonological structure of the base.

63 This generalisation does not apply to the suffix - wise, which also starts with a glide. The suffix -wise is not integrated into the pword of the stem as is shown by LOI violations in words like cloc[k.w]ise (cf. in[.kw]ire 'inquire'). The suffix -wise was originally an independent word which like other so-called 'semi-suffixes' appears to still constitute a separate pword (cf. Marchand 1969: 358).

64 Of course, it is also conceivable that the constraint M-PARSE dominates * CLASH for the suffix -like, but not for -ize. That account misses a generalization, however, since all consonant-initial suffixes freely violate ${ }^{*} \mathrm{CLASH}$ whereas all vowel-initial suffixes except for 
-ee avoid vioations of *CLASH.

65 The function of pwords as domain for syllabification is expressed by the following two constraints, which align the edges of pwords with syllable boundaries (cf. also the discussion of the LOI violations discussed in section 2 (cf. (rump.) less, not $^{2}$ *(rum.p) $)_{\omega}$ less $\left.)\right)$ :

\author{
ALIGN PWORD \\ Align(Pword, L, $\sigma, \mathrm{L}$ ) \\ Align(Pword, R, $\sigma, \mathrm{R}$ )
}

The constraint ALIGN PWORD follows from the Prosodic Hierarchy and rules out candidates like (stíy.l) $)^{i}$ ize. The question of whether and under what conditions the Prosodic Hierarchy is violable in principle is a matter of debate. For example, how strong is the evidence for feet which span pword boundaries or for resyllabification across pword boundaries and what are the consequences for prosodic representation? In English the Prosodic Hierarchy consistently holds in the lexicon. Assuming that ALIGN PWORD implies just that each segment within a pword must be associated with a syllable within that pword this constraint is also not violated by the ambisyllabicity resulting from the association of pword-final consonants with the syllable of a following vowel-initial word (cf. note 76).

66 A similar issue arises for Nespor and Vogel's (1986) analysis of Italian prefixes. The authors propose that all consonant-final prefixes are integrated into the pword of the stem. This analysis suggests that the constraint ONSET or the constraint NOCODA, which prohibits segments in the syllable coda, dominate a constraint which aligns the right edge of a prefix with the left edge of a pword. However, when attaching to consonant-initial stems the integration of consonant-final prefixes never serves to satisfy ONSET and in many cases also fails to satisfy NOCODA (e.g. com+piacere 'please', sub+dolo 'underhand') which raises the question of how integration of consonant-final prefixes can be formally described in such cases. In Vogel's (1994) analysis of the prosodic structure of Italian prefixes the distinction between consonants and vowels plays no role (cf. also Peperkamp 1997).

76 The only German consonant-initial suffixes which have undergone vowel reduction and thus do not constitute separate pwords are -chen and -sel. These exceptions are perhaps not accidental. The suffix -chen differs from other German suffixes in that its initial consonant is a palatal fricative, which is not allowed in word-initial position. The constraint in question is violated only in names and recent loanwords in northern standard NHG (e.g. China 'China', Chemnitz 'Chemnitz', Chemie 'chemistry'). Plausibly, as a result of the violation of this phonotactic constraint the suffix -chen cannot be parsed as a pword. The suffix - sel is a reduced variant of the suffix -sal (i.e. [za:l]), which does constitute a pword. Some conditions under which reduction took place are discussed in Wilmanns (1896: 272). The suffixes -chen and -sel are perhaps best represented as clitics (cf. the discussion of the English consonant-initial suffixes at the end of section 6).

68 As a result of this constraint there are variant pronunciations like máy[hغे]m or $m a ́ y[ə] m$, but not *máy[hə] $m$. The constraint against the sequence [hə] also accounts for the stability of penultimate stress in words like inhérent, cohérent, abhórrent (cf. réferent, ignorant, pértinent) and the stability of final stress in words like cóhòrt (cf. cóncert, yógurt, cómfort). Interestingly the sequence [hə] is allowed in pword-initial position in 
English (cf. ([hə]mogenous) $)_{\omega}$ 'homogenous', ([hə]lucinate) $\omega_{\omega}$ 'hallucinate'. Failure of vowel reduction in the suffix -hood thus supports the claim that consonant-initial suffixes are not pwords.

69 If followed by a non-coronal obstruent vowels reduce only if they are preceded by a stressed light syllable (e.g. [ǽrəb]- [éyræ̀b] 'Arab', [bíšəp] 'bishop'- [pársnìp] 'parsnip'). The suffix -ship is never preceded by a light syllable with the result that the vowel cannot reduce.

70 Conceivably, these two suffixes differ from other English consonant-initial suffixes in that they are still analysed as a separate pword. Both -like and -wise suffixation originated historically as compounding whose respective rightmost member continue to exist as independent words. Also the meaning of those words can still be recognized in the suffixes -like and -wise, respectively. These properties distinguish the suffixes -like and -wise from other English consonant-initial suffixes.

71 The claim that the prosodic integration of clitics can depend on the question of whether they have an onset is also supported by the Dutch consonant-initial third person singular pronoun hij [hei], which differs from the equivalent vowel-initial pronoun ie [i] in that it is not integrated into the pword of its (preceding) host (cf. Booij and Lieber 1993).

72 The structures in (82) do not conform to the Strict Layer Hypothesis proposed in Nespor and Vogel (1986) since prosodic categories are not necessarily dominated by categories on the next higher level. Evidence against that version of the Strict Layer Hypothesis is discussed in Ladd $(1986,1996)$, Vogel (1994), Selkirk (1995), Peperkamp (1997).

73 The fact that consonant-initial suffixation in English typically originated as compounding indicates that the reduction exhibited by the suffixes in $(81),(82)$ is due to a successive decay of prosodic structures: the decay of the pword and subsequently the decay of the foot. It appears that the German cognates of the consonant-initial suffixes in (81) continue to be dominated by pwords.

74 Of course a foot which is dominated by a pword can also be unstable. However in such cases instability is governed by independent conditions which determine the wellformedness of word-internal stress contours (cf. the loss of stress due to the constraint *CLASH illustrated in (11b)).

75 This is because consonant-initial suffixes historically started out as the righthand member of compounds, which exhibited a strong-weak stress pattern (cf. (árm) (chàir) $_{\omega}$, $(\operatorname{lámp})_{\omega}$ (pòst) $)_{\omega}$, etc.). The decay of the prosodic structure in the suffix thus started out with the loss of the pword category, with the subsequent loss of the foot category in English. The decay of prosodic structure always presupposes that the category in question is labeled weak. Cf. also note 81 for the German data.

76 It is unclear whether or not ambisyllabicity of pword-final consonants must be considered a violation of the Prosodic Hierarchy on the phonetic level (cf. note 65). At any rate the association of such consonants with the coda before a stressed vowel is clearly indicative of an intervening pword boundary. Also this type of Prosodic Hierarchy violation satisfies the condition that syllabification rules are only structure-building, but may not change structure (cf. Steriade 1982). None of these properties hold for phonetic resyllabification across pword boundaries as proposed in Nespor and Vogel (1986), Kang (1992), Hannahs (1995).

77 The effect in question occurs also across word boundaries in phrases like [hıræl] 'hit 
Al'.

78 I leave open the question of how to represent the highest node in compounds.

79 The possibility that the $t$ is syllabified exclusively in onset position and also occupies the final position in the pword is ruled out by the Prosodic Hierarchy (cf. also notes 65 and 76).

80 Stress neutrality in -ize suffixation is represented by ranking IDENT(S) higher than the constraint $*$ Lapse, which prohibits sequences of stressless syllables.

81 Cf. -lich-suffixations like $t a ̈[k .1] i c h$ 'daily', in which the syllable boundary clearly precedes the suffix although the cluster $k l$ is a wellformed syllable onset in German. The evidence from stress entirely correlates with the evidence from syllabi-fication and shows that consonant-initial suffixes are not integrated into the pword of the stem. Stress often falls on the word-final syllable in German (e.g. radikál 'radical', Elefánt 'elephant', Seminár 'seminar'), but this is never the case when the final syllable belongs to a consonant-initial suffix (i.e. entzíffer+bàr 'decipherable', Mútter+schàft 'motherhood', áufmerk+sàm 'attentive', Müh+sàl 'tribulation'). In German the stress-pattern of words with consonant-initial suffixes corresponds thus to the stress pattern of compounds (i.e. strong weak), which further supports the claim that such suffixes usually form separate pwords in German.

82 The relevant constraint is satisfied by '-el-insertion' (e.g. Dách+chen 'roof'-Dächelchen 'little roof').

83 According to the Prosodic Hierarchy, which requires that feet are properly contained within pwords, consonant-initial suffixes which are not integrated into the pword of the stem cannot exhibit stress-related phonological effects. Specifically such suffixes cannot be associated with output constraints on foot structure where the foot includes material from both the stem and the suffix. A putative counter-example to this generalization is cited by Féry (1997), who claims that -chen suffixation favors final trochees in the output forms. The evidence for this claim are regular truncations in -chen suffixation like Ófen+chen $\rightarrow$ Öfchen 'little stove', Áffe+chen $\rightarrow$ Äffchen 'little monkey'. However, the fact that only the string - $ə n$, but not - $ə l$ or - $ə r$, delete indicates that truncation is motivated not by metrical constraints but by rhyme dissimilation here. There are even cases of regular-al-insertion to avoid clusters of velar fricatives in output forms (cf. the preceding note). Truncation of word-final schwa as in Affe+chen $\rightarrow$ Äffchen 'little monkey' is not motivated by a preference for trochees either as it also applies in compounds like Auge+ Apfel $\rightarrow$ Áugàpfel 'eye apple', Birne+Baum $\rightarrow$ Bírnbàum pear tree', Erde+Beben $\rightarrow$ Érdbèben 'earth quake', etc.

84 The level in question corresponds roughly to the output of the lexicon in Lexical Phonology. Clearly the relevant representations must include word stress in English, but not necessarily syllable structure, which may account for the absence of identity effects in syllable structure (cf. the discussion in section 3).

85 The fact that intensive $s$ never attaches to words with an initial fricative reflects an OCP constraint against fricative clusters. The absence of $s$-prefixations based on vowel-initial words is discussed in note 107 .

86 To rule out the form *[zb]ash the constraint AGREE vOICE could be replaced by a constraint which requires that all obstruent clusters are voiceless. The domain of that constraint is the syllable as is shown by the occurrence of heterosyllabic voiced obstruent clusters (cf. le[zb]ian). As was noted by Kahn (1976) English words which include tautosyllabic voiced clusters are always bimorphemic (e.g. le [gz] 'legs', bi[dz] 'bids'). The oc- 
currence of such voiced clusters therefore indicate that identity constraints dominate the constraint which requires that all obstruent clusters are voiceless.

87 Are there counter-examples to the condition that identity constraints can only affect distinctive features? In her analysis of truncated forms like English [lær] 'Lar' from [læ.ri] 'Larry', Benua (1995) argues that identity effects can also pertain to 'allophonic properties' of words. Generally the vowels $[æ]$ and $[a]$ are in complementary distribution before [r]. The vowel [æ] appears before heterosyllabic [r] (e.g. [kæ.ri] 'carry') and [a] appears before tautosyllabic [r] (e.g. [kar] 'car'). The appearance of [æ] rather than [a] before tautosyllabic [r] in the truncated form is accordingly clearly an identity effect. However, the question not asked by Benua is whether or not this identity effect is possible only in in case the relevant vowels do contrast in other environments (e.g. [kæm] 'cam' vs. [kam] 'calm'). If such a correlation existed the truncation data would be unproblematic because the identity constraints would pertain to phonemic representations. If not it should be investigated whether or not phonetic identity effects are found only in truncation and if so why truncation differs from other word formation rules.

88 Additional examples are $X$ [éyšən]-X[èyt], X[əfəkéyšən]-X[əfày], X[əzéyšən]-X[àyz], $\mathrm{X}$ [x́ləti]-X[ə1]. Significantly, the notion of subcategorization plays no role in word formation based on correlative patterns. Such formations should therefore not be cited as evidence in support of restrictions on input forms (cf. section 10).

89 As was shown in section 4.1. an adequate description of the systematic differences between the phonologically similar suffixes -eer, $-e s e_{1}$, and -ee alone would call for the positing of three distinct levels which precede the 'neutral' level. Note further that the suffixes which exhibit the same stress-related effects as -eer differ in other phonological effects. To account for these differences additional levels would have to be posited. In fact, an adequate description of the systematic aspects of English morphophonology would require a separate level for each vowel-initial suffix in addition to a level for all consonant-initial suffixes.

90 Cf. LOI violations in words like rum[p.l]ess, which consist of a single foot according to Burzio.

91 Cf. Ross (1972) for a critical discussion of the abstractness in Chomsky and Halle's (1968) description of English stress.

92 Actually, reference to any of these abstractions does not allow for a description of the systematic differences in the stress patterns between -ee, -eer, and -ese affixation. Burzio claims that such 'auto-stressed' suffixes are exceptional in that it is not possible to account for their stress behavior on the basis of their phonological form. By contrast, I have argued that the suffixes -eer and -ese are similar to other English suffixes in that they avoid violations of the constraint ${ }^{*} \mathrm{CLASH}$.

93 Perhaps, the low productivity of the suffixes -ful, -dom, or -some is partially due to the labial consonants (cf. note 24). The fact that -less is much more productive than -ful appears to be due also to semantics. For example, the existence of pilotless but not *pilotful aircraft, ticketless but not *ticketful travel is apparently due to semantic rather than phonological restrictions on -ful-suffixation contrary to Burzio's analysis.

94 The same explanation applies to -hood suffixation, which is also rarely based on dactyls, although that suffix can constitute a separate foot on Burzio's account.

95 The observation that semantic stability in the relation between cognates is determined by phonological identity conditions constitutes the basis for the morphological analysis model developed in Raffelsiefen $(1993,1998)$. Semantic stability is taken to in- 
is clear evidence that $i N$ - is not integrated into the pword of the stem as is shown in Raffelsiefen (1993: 97ff). There it is proposed to account for assimilation in terms of not the prosodic but rather the segmental representation of that prefix.

102 Booij (1998) rejects affix-specific constraint rankings because he considers such a grammar implausible from the point of view of language acquisition. However, assuming that constraints are innate and given that the number of both affixes and the constraints associated with each affix is rather small learnability might not pose a problem. As is shown in this paper the empirical evidence for affix-specific constraint rankings in English is rather strong.

103 Inflectional affixes which exhibit phonologically conditioned gaps are rare but they do exist. In Swedish there is an agreement suffix $-t$ which marks neuter adjectives. This suffix does not attach to adjectives which end in a long voiced alveolar stop as is illustrated in (id). The forms in question are avoided altogether according to Norstedts Stora Svenska Ordbok (1988).

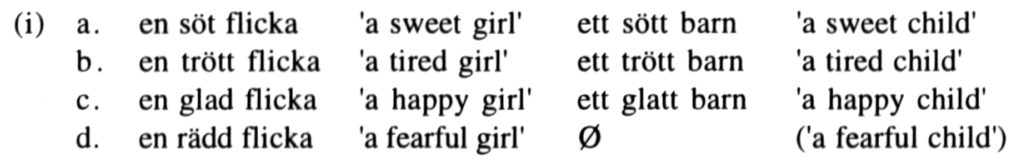

The insight that the gap in question requires reference to constraints rather than rules was first expressed in Eliasson (1981).

104 If dactyls were disallowed one would have to posit prosodic subcategorization frames to the effect that the disyllabic suffix - ery attaches to monosyllabic stems (cf. brib+ery, róbb+ery, etc) whereas the monosyllabic suffix -ry attaches to disyllabic stems (cf. ríval+ $r y$, rével $+r y$, etc). Such an approach would obviously fail to express the relevant generalization.

105 The features [+obstruent] and [+coronal] are matched by the corresponding feature values in the stem-final consonant. The feature [+palatal] is matched by the corresponding value in the affix-initial glide.

106 According to Booij (1998) the Dutch suffix -aar occurs after stems which end in schwa followed by $/ \mathrm{r}, \mathrm{l}, \mathrm{n} /$, which in fact are the most sonorous consonants according to Zwicky (1972). However, the segmental restriction to those sonorants presumably just follows from the restriction to stems which end in schwa syllables since with few exceptions no consonants other than $/ \mathrm{r}, 1, \mathrm{n} /$ follow schwa in word-final position. That is, in terms of output forms the stressed suffix -aar is associated with both * CLASH and IDENT(S), but not with a constraint on the sonority of syllable onsets.

107 A particularly problematic case for output constraints is the rule of negative $s$-prefixation in Italian. In general the prefix attaches as long as the resulting cluster does not violate Italian phonotactics (cf. Muljacic 1969) and seems thus a prime example for output constraints (cf. (ia) versus (ib)). However, the prefix also fails to attach to vowel-initial stems as is illustrated in (ic). The examples in (i) are adopted from Scalise (1984: 48):
(i)a. fortunato - sfortunato
'lucky' 'unlucky'
leale - sleale
'loyal' 'disloyal'
b. sano - *ssano
'healthy'
sensibile - *ssensibile
'sensitive'
c. umano - *sumano
'human'
onesto - *sonesto
'honest'




$$
\begin{aligned}
& \text { gradevole - sgradevole sicuro - *ssicuro educato - *seducato } \\
& \text { 'pleasant' 'unpleasant' 'secure' 'well-mannere' }
\end{aligned}
$$

The gap in (ic) is hardly arbitrary since the same restriction applies to intensive $s$-prefixations in English. What is wrong with attaching a single consonant to a vowel- initial stem? Intuitively, the problem is that such a consonant would be somehow 'pre-empted' by its phonological function, i.e. to serve as a syllable onset, and therefore could no longer function as a morphological marker. On this view the explanation of the gap is output-oriented but it is unclear how the constraint in question should be formulated.

108 Assuming that the constraints in (109) are innate the relevant phonological effects are expected to occur cross-linguistically. For example the constraint $* \mathrm{~L}_{\mathrm{i}} \mathrm{L}_{\mathrm{i}}$ is manifested in phonological effects in many languages which are not genetically related to English. The Khalkha-Mongolian suffix -u:r denotes tools (e.g. xana 'to bleed'-xanu:r 'lancet', ölgö 'to hang up'-ölgü: $r$ 'knot'. When the base contains an $r$ the suffix is -u:l instead (e.g. bari 'to grasp'-bariu:l 'handle') (cf. Poppe 1951: 33). The Georgian suffix -ur derives adjectives from nouns (e.g. xalxi 'people'-xalxuri 'popular', jağli 'dog'-jağluri 'canine'). When the base contains an $r$, the suffix is - $u l$ instead (e.g. gmiri 'hero'-gmiruli' 'heroic') (cf. Aronson 1982: 95). The Lezgian suffix -ra marks the oblique stem (e.g. lam 'donkey'-lamra, luk' 'slave'-luk'ra). The $r$ is not preserved in a stem-final cluster $r \mathrm{C}$ (e.g. werč 'hen'-wečra) (cf. Haspelmath 1993: 63, 77).

109 This restriction is inspired by Vennemann's preference laws for syllable structure which are largely motivated by historical sound change (cf. Vennemann 1988).

\section{REFERENCES}

Aronoff, M. and S.N. Sridhar. 1983. "Morphological Levels in English and Kannada; or Atarizing Reagan". In J. Richardson, M. Marks and A. Chuckerman (eds), Papers from the Parasession on the Interplay of Phonology, Morphology and Syntax. Chicago: Chicago Linguistics Society, 3-16.

Aronson, H. I. 1982. Georgian. A Reading Grammar. Columbus Ohio: Slavica Publishers, Inc.

Bauer, L. 1992. "Scalar Productivity and -lily Adverbs". In G. Booij and J. van Marle (eds), Yearbook of Morphology 1991. Dordrecht: Kluwer Academic Publishers, 185191.

Benua, L. 1995. "Identity Effects in Morphological Truncation". In J. Beckman, S. Urbanczyck and L. Walsh (eds), Papers in Optimality Theory. University of Massachusetts Occasional Papers in Linguistics 18. Graduate Linguistics Student Association, Amherst, Massachusetts, 77-136.

Booij, G. 1985. "Coordination Reduction in Complex Words: a Case for Prosodic Phonology". In H. van der Hulst and N. Smith (eds), Advances in Nonlinear Phonology. Dordrecht: Foris, 143-159.

Booij, G. 1998. "Phonological Output Constraints in Morphology". In W. Kehrein and R. Wiese (eds), Phonology and Morphology of the Germanic languages. Tübingen: Niemeyer, 141-163.

Booij, G. \& R. Lieber. 1993. "On the Simultaneity of Morphological and Prosodic Structure". In S. Hargus and E. Kaisse (eds), Studies in Lexical Phonology. San Diego: 
Academic Press, 34-44.

Brame, M. 1974. "The Cycle in phonology: Stress in Palestinian, Maltese and Spanish". Linguistic Inquiry 5, 39-60.

Burzio, L. 1994. Principles of English stress. Cambridge: Cambridge University Press.

Chomsky, N. and M. Halle. 1968. The Sound Pattern of English. New York: Harper and Row.

Drosdowski , G. (ed.). 1990. Duden Aussprachewörterbuch: Wörterbuch der deutschen Standardaussprache. Mannheim, Wien, Zürich: Dudenverlag.

Eliasson, S. 1981. "Analytic vs. Synthetic Aspects of Phonological Structure". In D.L. Goyvaerts (ed.), Phonology in the 1980's. Ghent: E. Story-Scientia, 483-524.

Féry, C. 1997. "Uni und Studis: die besten Wörter des Deutschen". Linguistische Berichte 172, 461-489.

Fidelholtz, J. 1967. English Vowel Reduction. Ms. Cambridge: M.I.T.

Fudge, E. 1984. English Word-stress. London: George Allen and Unwin.

Halle, M. and K.P. Mohanan. 1985. "Segmental Phonology of Modern English". Linguistic Inquiry 16, 57-116.

Hannahs, S. 1995. "The Phonological Word in French". Linguistics 33, 1125-1144.

Haspelmath, M. 1993. A Grammar of Lezgian. Berlin; New York: Mouton de Gruyter

Inkelas, S. 1990. Prosodic Constituency in the Lexicon. Doctoral dissertation, Stanford University 1989. (Reprinted by Garland, New York)

Jones, D. and A.C. Gimson. 1977. Everyman's English Pronouncing Dictionary. Fourteenth ed.. London, Melbourne and Toronto: J.M. Dent and Sons Ltd.

Kahn, D. 1976. Syllable-based Generalizations in English Phonology. New York: Garland Press.

Kang, O. 1992. Korean Prosodic Phonology. Doctoral dissertation, University of Washington.

Kenyon, J.S. and T.A. Knott. 1944. A Pronouncing Dictionary of American English. Springfield, MA: Merriam.

Kiparsky, P. 1982. "Lexical Morphology and Phonology". In I. Yang (ed.), Linguistics in the Morning Calm. Seoul: Hanshin, 3-91.

Ladd, R. (1986) "Intonational Phrasing: The Case for Recursive Prosodic Structure". Phonology Yearbook 3, 311-340.

Ladd, R. 1996. Intonational Phonology. Cambridge: Cambridge University Press.

Libermann, M and A. Prince. 1977. "On Stress and Linguistic Rhythm". Linguistic Inquiry 8, 249-336.

Luick, K. 1964. Historische Grammatik der Englischen Sprache. Oxford: Basil Blackwell. (Originally published between 1914 and 1940 by Bernhard Tauchnitz Verlag, Stuttgart.)

Marchand, H. 1969. The Categories and Types of Present-day English Word Formation. Second ed. München: Beck.

McCarthy, J. J. and A. S. Prince. 1993. Prosodic Morphology I: Constraint Interaction and Satisfaction. Ms., University of Massachusetts, Amherst and Rutgers University, New Brunswick.

McCarthy, J. J. and A. S. Prince. 1995. "Faithfulness and Reduplicative Identity". To appear in René Kager, Harry van der Hulst and Wim Zonneveld (eds), Proceedings of the OTS/HIL Workshop in Prosodic Morphology. Cambridge: Cambridge University Press. 
Muljačič, Z. 1969. Fonologia generale e fonologia della lingua italiana. Bologna: II Mulino.

Myers, S. 1987. "Vowel Shortening in English". Natural Language and Linguistic Theory 5, 485-518.

Nespor, M. and I. Vogel. 1986. Prosodic Phonology. Dordrecht. Foris.

Newman, S.S. 1946. "On the Stress System of English". Word 2, 171-187.

Norstedts Stora Svenska Ordbok. 1988. Second ed.. Förlagsaktiebolaget OTAVA, Keuru.

Pater, J. 1995. On the Nonuniformity of Weight-to-Stress and Stress Preservation Effects in English. Ms. McGill University.

Peperkamp, S. 1997. Prosodic words. The Hague: Holland Academic Graphics.

Poppe, N. 1951. Khalkha-Mongolische Grammatik. Wiesbaden: Franz Steiner Verlag.

Prince, A. and P. Smolensky. 1993 Optimality Theory: Constraint Interaction in Generative Grammar. Ms. Rutgers University and University of Colorado, Boulder.

Raffelsiefen, R. 1992. "A Nonconfigurational Approach to Morphology". In M. Aronoff (ed.), Morphology Now. Albany, NY: State University of New York Press, 133-162.

Raffelsiefen, R. 1993. "Relating Words. A Model of Base Recognition. Part 1". Linguistic Analysis 23, 3-159.

Raffelsiefen, R. 1996. "Gaps in Word Wormation". In U. Kleinhenz (ed.), Interfaces in Phonology. Berlin: Akademie Verlag, 194-209.

Raffelsiefen, R. 1998. "Semantic Stability in Derivationally Related Words". In R.M. Hogg and L.van Bergen (eds), Historical Linguistics 1995, Vol. 2. Amsterdam/ Philadelphia: Benjamins, 247-267.

Ross, J.R. 1972. "A Reanalysis of English Word Stress (part I)". In M. Brame (ed.), Contributions to Generative Phonology. Austin: University of Texas Press.

Scalise, S. 1984. Generative Morphology. Dordrecht: Foris.

Selkirk, E. 1982. The Syntax of Words. Cambridge, Mass.: MIT Press.

Selkirk E. 1995. "The Prosodic Structure of Function Words". In J. Beckman, S. Urbanczyck and L. Walsh (eds), Papers in Optimality Theory. University of Massachusetts Occasional Papers in Linguistics 18. Graduate Linguistics Student Association, Amherst, Massachusetts, 439-469. (Also published in J. Morgan and K. Demuth (eds). 1996. Signal to Syntax: Bootstrapping from Speech to Grammar in Early Acquisition. Mahwah, NJ: Lawrence Erlbaum Associates, 187-213).

Siegel, D. 1974. Topics in English Morphology. Garland. New York.

Stampe, D. 1972. How I Spent my Summer Vacation. Doctoral dissertation, Ohio State University.

Steriade, D. 1982. Greek Prosodies and the Nature of Syllabification. Doctoral dissertation, MIT.

The Oxford English Dictionary. 1993. Second ed.. Oxford: Oxford University Press

Vennemann, T. 1988. Preference Laws for Syllable Structure and the Explanation of Sound Change. Berlin, New York: Mouton de Gruyter.

Vogel, I. 1994. "Phonological Interfaces in Italian". In M. Mazzola (ed.), Issues and Theory in Romance Linguistics: Selected Papers from the Linguistic Symposium on Romance Languages XXIII. Washington, D.C.: Georgetown University Press, 109-126.

Walker, J. (1826) A Critical Pronouncing Dictionary, and Expositor of the English Language. London and Leipsic [Leipzig]. 
Wells, J.C. (1982) Accents of English I: an Introduction. Cambridge: Cambridge University Press.

Wiese, R. 1996. "Prosodic Alternations in English Morphophonology: a Constraintbased Account of Morpheme Integrity". In J. Durand and B. Laks (eds), Current Trends in Phonology: Models and Methods, volume 2. Salford: European Studies Research Institute, University of Salford, 731-756.

Wilmanns, W. 1896. Deutsche Grammatik. Zweite Abteilung: Wortbildung. Strassburg: Verlag von Karl J. Trübner.

Zwicky, A. 1972. "A Note on a Phonological Hierarchy in English". In R.P. Stockwell and R.K.S. Macaulay (eds), Linguistic Change and Generative Theory. Bloomington: Indiana University Press, 275-301.

Freie Universität Berlin

Institut für Englische Philologie

Gosslerstraße 2-4

D-14195 Berlin

Germany 